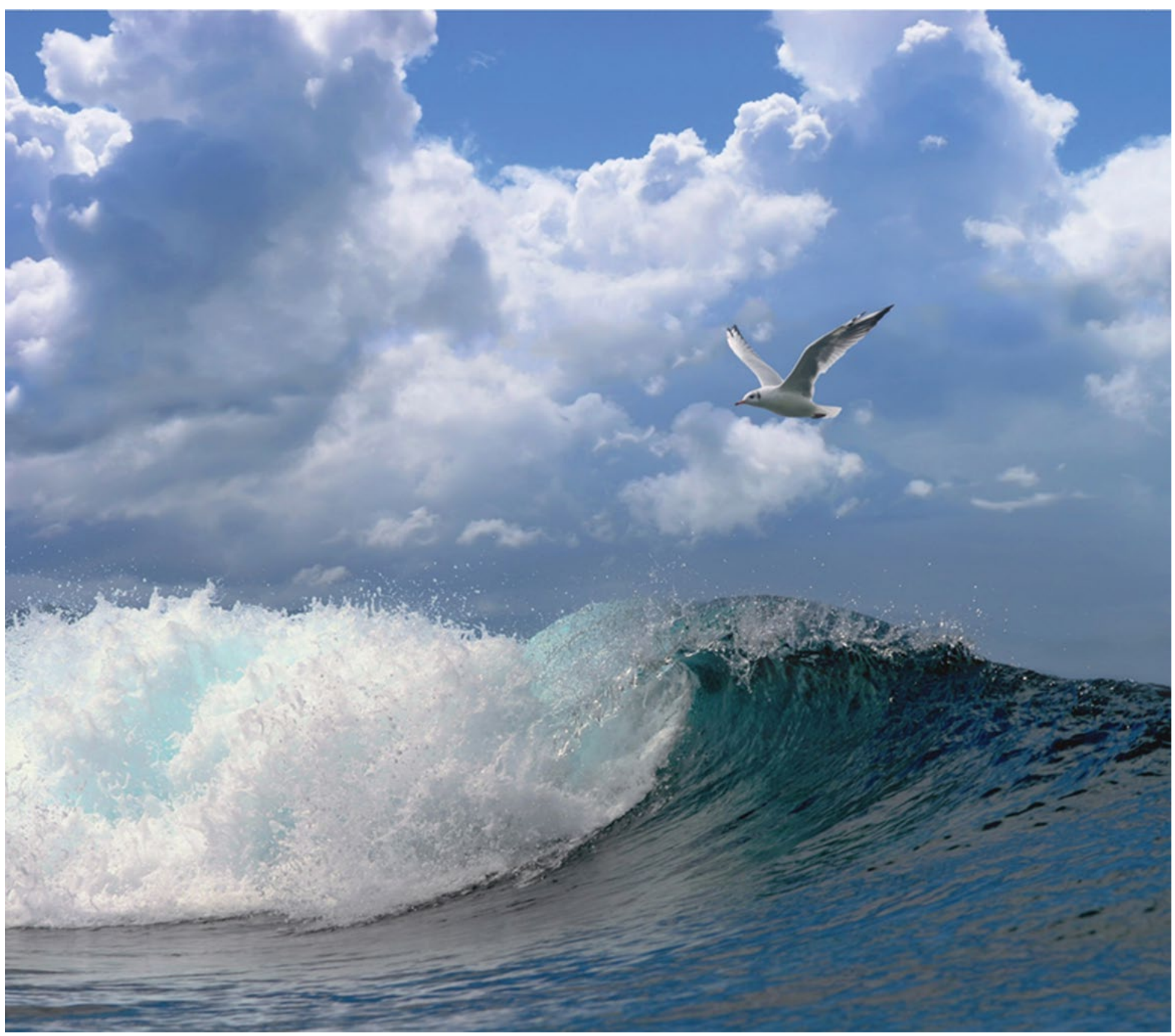

De mogelijke rol van de Filipijnse tapijtschelp in de voedselvoorziening voor vogels in de Oosterschelde en het Grevelingenmeer 


\section{De mogelijke rol van de Filipijnse tapijtschelp in de voedelvoorziening voor vogels in de Oosterschelde en het Grevelingenmeer}

Pauline Kamermans \& Mardik Leopold

Wageningen Marine Research

Dit onderzoek is uitgevoerd door Wageningen Marine Research en gesubsidieerd door het Ministerie van Landbouw, Natuur en Voedselkwaliteit, in het kader van het Beleidsondersteunend onderzoekthema 'Duurzame voedselvoorziening \& -productieketens \& Natuur' (projectnummer BO-43-119.01-019) 
Keywords: Tapijtschelp, Oosterschelde, Scholekster.

Opdrachtgever: $\quad$ LNV directie VLG

T.a.v.: J.M.M. Kouwenhoven

Bezuidenhoutseweg 73

2594 AC Den Haag

BAS code: BO-43-119.01-019

Dit rapport is gratis te downloaden van https://doi.org/10.18174/548650

Wageningen Marine Research verstrekt geen gedrukte exemplaren van rapporten.

Wageningen Marine Research is ISO 9001:2015 gecertificeerd.

Foto omslag:

\section{(c) Wageningen Marine Research}

Wageningen Marine Research, instituut binnen de rechtspersoon Stichting

Wageningen Research, hierbij

vertegenwoordigd door

Dr.ir. J.T. Dijkman, Managing director

KvK nr. 09098104,

WMR BTW nr. NL 8113.83.696.B16.

Code BIC/SWIFT address: RABONL2U

IBAN code: NL 73 RABO 0373599285
Wageningen Marine Research aanvaardt geen aansprakelijkheid voor gevolgschade, noch voor schade welke voortvloeit uit toepassingen van de resultaten van werkzaamheden of andere gegevens verkregen van Wageningen Marine Research. Opdrachtgever vrijwaart Wageningen Marine Research van aanspraken van derden in verband met deze toepassing.

Alle rechten voorbehouden. Niets uit deze uitgave mag weergegeven en/of gepubliceerd worden, gefotokopieerd of op enige andere manier gebruikt worden zonder schriftelijke toestemming van de uitgever of auteur. 


\section{Inhoud}

Samenvatting

$1 \quad$ Inleiding $\quad 6$

$\begin{array}{lll}1.1 & \text { Tapijtschelpen } & 6\end{array}$

$\begin{array}{lll}1.2 & \text { Vogels en hun voedselaanbod } & 7\end{array}$

2 Kennisvraag $r 9$

3 Methoden $r$

$4 \quad$ Resultaten en discussie $r$

4.1 Vergelijking kokkels en tapijtschelpen 11

4.1.1 Morfometrie kokkels en Filipijnse tapijtschelpen $\quad 11$

4.1.2 Dichtheid kokkels en tapijtschelpen in de Oosterschelde $\quad 14$

$\begin{array}{lll}4.1 .3 & \text { Ingraafdiepte kokkels en tapijtschelpen } & 15\end{array}$

4.1.4 Temperatuurtolerantie van kokkels en tapijtschelpen 16

4.2 Filipijnse tapijtschelpen als voedsel voor vogels in de Oosterschelde en het
Grevelingenmeer

4.2.1 Kennisvragen A en B: kan de Filipijnse tapijtschelp een volwaardige (en/of aanvullende) voedselbron zijn, welke evidentie is hiervoor en welke kennis ontbreekt nog?

4.2.2 Kennisvraag C: Uitgaande van een minimummaat van kokkels van $21 \mathrm{~mm}$ : is op basis van 'expert judgement' een minimummaat voor visserij te adviseren van tapijtschelpen?

4.2.3 Kennisvraag D: Voor welke vogelsoorten kunnen Filipijnse tapijtschelpen in de Oosterschelde en het Grevelingenmeer een volwaardige en/of aanvullende voedselbron vormen? Daarbij wordt ook meegenomen in welke mate deze soorten gebruik maken van de Oosterschelde en het Grevelingenmeer in vergelijking met andere Nederlandse (kust)wateren.

4.2.4 Kennisvraag E: Indien tapijtschelpen inderdaad als volwaardige alternatieve (en/of aanvullende) voedselbron aangemerkt kunnen worden, welke consequenties zou dit kunnen hebben voor de voedselreservering voor scholeksters in de Oosterschelde? 


\section{Samenvatting}

De Filipijnse tapijtschelp heeft in de Oosterschelde een bestandsomvang bereikt die iets minder dan de helft is van het kokkelbestand. Op kokkels kan worden gevist, mits de voorraad voldoende is voor de scholeksters in het gebied, en de laatste jaren was dit niet het geval. Daarbij vertoonden kokkels in recente jaren grote zomersterfte, waardoor het bestand verder terugliep. Tapijtschelpen kunnen mogelijk beter tegen hete zomers dan kokkels en zouden, gezien de voortgaande opwarming, de functie van de kokkel in het ecosysteem over te gaan kunnen nemen, zowel als voedsel voor scholeksters als voor de visserij. De vraag ligt voor of Filipijnse tapijtschelpen in de Oosterschelde kunnen bijdragen aan voedselvoorziening van scholeksters en of hierdoor de rekenregels voor de voedselreservering kunnen worden aangepast. Om deze vraag nader te adresseren zijn vijf kennisvragen beantwoord:

A. Is uit bestaande literatuur bekend of (en in welke mate) Filipijnse tapijtschelpen een volwaardige (en/of aanvullende) voedselbron kunnen zijn? en

B. Welke onderbouwing is daarbij gevonden en welke noodzakelijke kennis ontbreekt eventueel? Een analyse van kokkels en tapijtschelpen liet zien dat deze twee soorten een vergelijkbare morfometrie hebben. Het belangrijkste verschil is dat de range in afmetingen groter is voor tapijtschelpen. Literatuuronderzoek geeft aan dat de ingraafdiepte van tapijtschelpen binnen de reikwijdte van scholeksters valt. Er wordt aangenomen dat kokkels met een dichtheid lager dan 50 per $\mathrm{m}^{2}$ niet profijtelijk zijn voor scholeksters. Uit de bestandsopnamen blijkt dat tapijtschelpen ook voorkomen in dichtheden boven 50 per $\mathrm{m}^{2}$. Tapijtschelpen tolereren hogere temperaturen dan kokkels en zijn wellicht meer toekomstbestendig dan kokkels in de Delta. Uit een Britse studie blijkt dat scholeksters alle maten tapijtschelpen aten die in de wadbodem voorradig waren, zonder noemenswaardige grootteselectie en dat gedurende het onderzoek het percentage vogels dat zich specialiseerde op tapijtschelpen, of die tapijtschelpen naast andere prooien aten, toenam. Foerageren op tapijtschelpen bleek voor de vogels even profijtelijk als foerageren op kokkels.

C. Uitgaande van een minimummaat van kokkels van $21 \mathrm{~mm}$ : is op basis van 'expert judgement' een minimummaat voor visserij te adviseren van tapijtschelpen?

De minimummaat van kokkels voor visserij is $21 \mathrm{~mm}$ schelplengte. Deze maat is gebaseerd op het vleesgehalte dat nog verkoopbaar is. De minimummaat spaart daarnaast de eenjarigen. Deze groep plant zich over het algemeen nog niet voort en kan dan opgroeien en een keer paaien in het voorjaar voordat ze wordt opgevist in het najaar. Ook voor tapijtschelpen geldt dat de eenjarigen kleiner zijn dan $21 \mathrm{~mm}$. In de mechanische kokkelvisserij is de afstand tussen de spijlen in de molens minimaal $15 \mathrm{~mm}$. Hiermee worden zowel de kokkels als de tapijtschelpen kleiner dan $21 \mathrm{~mm}$ lang gespaard. In de praktijk hoeft daarom de afstand tot te spijlen niet te worden aangepast en kan een gelijke minimummaat, van $21 \mathrm{~mm}$ schelplengte, voor beide soorten worden aangehouden.

D. Voor welke vogelsoorten kunnen Filipijnse tapijtschelpen in de Oosterschelde en het Grevelingenmeer een volwaardige en/of aanvullende voedselbron vormen?

Schelpdieren worden door vier groepen van vogels gegeten: eenden, steltlopers, meeuwen en kraaien. Schelpdier-etende soorten die hier relevant zijn, dat wil zeggen tamelijk algemeen voorkomen en een Natura 2000-status hebben zijn: scholekster en brilduiker in het Grevelingenmeer en bergeend, bonte strandloper, drieteenstrandloper, kanoet, rosse grutto, scholekster, steenloper, wulp en zilverplevier in de Oosterschelde. In Nederland is geen onderzoek gedaan naar de rol van de Filipijnse tapijtschelp als prooisoort voor vogels. Het is daarom nog voor geen enkele vogelsoort duidelijk of deze in het Grevelingenmeer of in de Oosterschelde tapijtschelpen eten. Om vast te stellen of Filipijnse tapijtschelpen door vogels in deze gebieden worden gegeten, is dieetonderzoek nodig middels gerichte observaties aan foeragerende vogels of door leeggegeten schelpen op het wad, of prooiresten in uitwerpselen te verzamelen. 
E. Indien tapijtschelpen inderdaad als volwaardige alternatieve (en/of aanvullende) voedselbron aangemerkt kunnen worden, welke consequenties zou dit kunnen hebben voor de voedselreservering voor scholeksters in de Oosterschelde?

Er zijn drie redenen te geven waarom het zinnig zou zijn om de bestaande regels ten aanzien van de voedselreservering te evalueren en eventueel te herzien:

1. Het bestand aan kokkels komt in de meeste jaren niet boven de grenswaarde voor visserij, vertoonde meermalen aanzienlijke zomersterfte, tapijtschelpen hebben hun intrede gedaan en het aantal scholeksters is gestaag achteruitgegaan in de Oosterschelde. De achterliggende reden van de achteruitgang van scholeksters is niet duidelijk, maar jaren van voedselreservering heeft deze neergang niet kunnen stoppen.

2. Bij de rekenmethode van Rappoldt et al. (2003), die ten grondslag ligt aan de huidige voedselreservering en bij de suggestie dat kokkels in dichtheden onder de 50 per vierkante meter voor scholeksters niet oogstbaar zouden zijn, zijn onlangs kanttekeningen gemaakt door GossCustard \& Stillman (2020); zij stellen een andere rekenmethode voor en geven daarvoor uitgebreid de argumenten.

3. Indien kan worden vastgesteld dat Filipijnse tapijtschelpen voor de scholeksters in de Oosterschelde min of meer gelijkwaardig zijn als voedsel als de kokkel, zou de hoeveelheid voor scholeksters oogstbaar vlees van beide soorten in de voedselreservering mee kunnen worden genomen. Een interessant punt in deze is dat de langjarige trend voor aantallen scholeksters in de hele Oosterschelde negatief is, maar dat juist in de twee deelgebieden waar de meeste tapijtschelpen liggen (centraal en oost) er recent sprake lijkt van stabilisatie of zelfs een voorzichtige toename in de aantallen scholeksters. Gezien het feit dat de reservering van $150 \mathrm{~kg}$ kokkelvlees voor de scholeksters in de hele Oosterschelde echter niet heeft geleid tot een stabilisatie van de aantallen, moet deze grenswaarde wellicht hoger komen te liggen. 


\section{Inleiding}

\subsection{Tapijtschelpen}

De Filipijnse tapijtschelp (wetenschappelijke naam Ruditapes philippinarum, ook wel Tapes philippinarum genoemd) is een marien tweekleppig weekdier dat tot $7,5 \mathrm{~cm}$ groot kan worden. De schelp is stevig ovaal-rechthoekig en geelwit, geelbruin of bruin met vaak vlekken, vlammen of een vvormig zigzagpatroon (Fig. 1). Aan de binnenzijde is de schelp soms felgekleurd lila, donkerpaars of okergeel. Het is een invasieve exoot die inmiddels algemeen voorkomt in Zeeland (Stichting Anemoon www.anemoon.org).
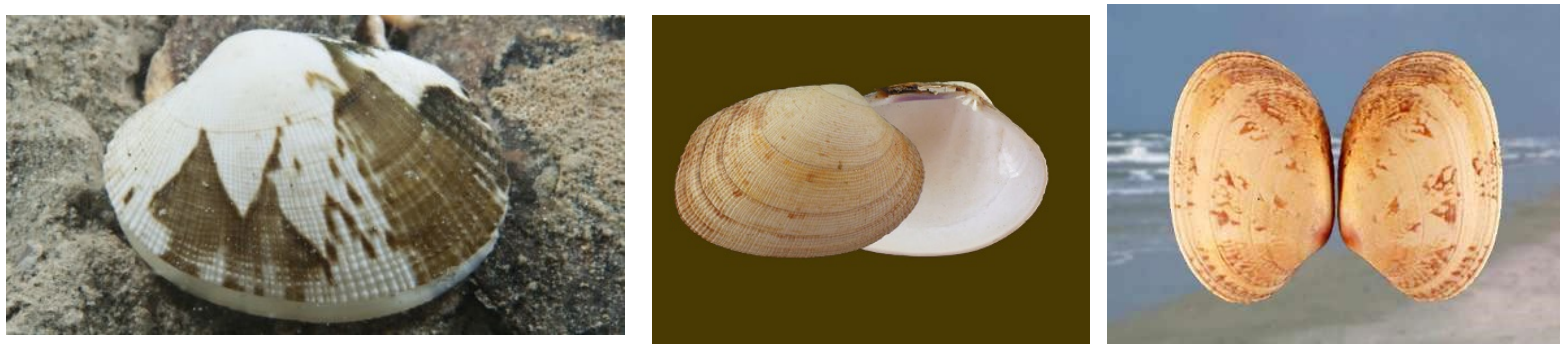

Figuur 1. De Filipijnse tapijtschelp (links), geruite tapijtschelp (midden) en gewone tapijtschelp (rechts). Bron: https://www.anemoon.org

De Filipijnse tapijtschelp lijkt op de inheemse soorten geruite tapijtschelp Ruditapes decussatus en gewone tapijtschelp Venerupis corrugata (Fig. 1), maar is te onderscheiden door zijn sifons. Van de Filipijnse tapijtschelp zijn die kort en zitten aan elkaar vastgegroeid, terwijl de sifons van de geruite tapijtschelp wat langer zijn en gescheiden van elkaar (Fig. 2) (Stichting Anemoon; Nerlovic et al., 2016). Onderscheid met de gewone tapijtschelp kan worden gemaakt door de ligging van de top te vergelijken. Deze ligt ver naast het midden bij de gewone tapijtschelp en slechts iets naast het midden bij de Filipijnse tapijtschelp (de Bruyne, 2004).

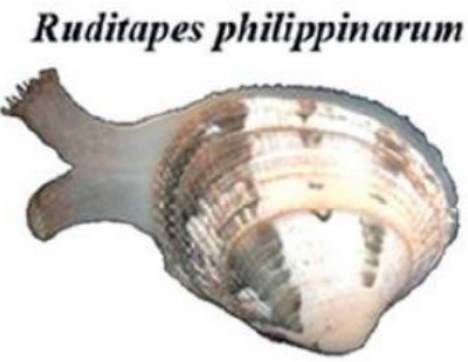

\section{Ruditapes decussatus}

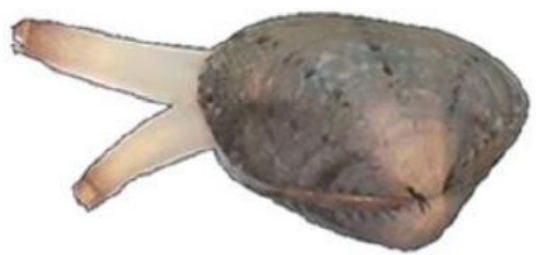

Figuur 2. Sifons van de Filipijnse (links) en geruite (rechts) tapijtschelp. Bron: Nerlovic et al., 2016.

Met zijn v-vormige strepen lijkt de soort ook op de venusschelp Chamelea striatula, een soort die voor Nederlandse vissers ook interessant kan zijn, maar die in Zeeland minder voorkomt dan in de Noordzee voor de Hollandse kust en benoorden de wadden (Stichting Anemoon www.anemoon.org; Troost et al., 2021)

De Filipijnse tapijtschelp is oorspronkelijk afkomstig uit Azië en geïntroduceerd in Europa voor aquacultuurdoeleinden, na een aantal eerdere succesvolle introducties in Hawaii en langs de westkust van Canada en de Verenigde Staten in de jaren 1920-40. Eenmaal geïntroduceerd in een geschikt habitat, gedraagt dit schelpdier zich als een agressieve, invasieve exoot, die hoge dichtheden en biomassa's kan bereiken (Caldow et al., 2007; Humphreys et al., 2015). In Europa is de soort eerst in 1972 in de baai van Archachon (Frankrijk) (Flassch \& Leborgne, 1992) uitgezet, daarna in 1982 in baaien in Ierland (Drummond et al., 2006), in 1983 in de lagune van Venetië (Italië) (Breber, 1985), 
en in 1987 in Noorwegen (Mortensen et al., 2000). Rond 2005-2008 is de soort ook in Nederland geïntroduceerd, wellicht als "meelifter" met mosselzaad dat destijds werd geïmporteerd vanuit Engeland, onder meer uit Poole Harbour, toen al een bekende groeiplaats van deze tapijtschelp (Jensen et al., 2004; Wijsman \& Smaal, 2006). De eerste exemplaren werden gevonden bij de oesterputten van Yerseke en bij Gorishoek (Tholen) in de oostelijke Oosterschelde (Faasse \& Ligthart, 2008; Titselaar, 2008). Ze worden thans ook gevonden in het Veerse Meer, het Grevelingenmeereer, in de Voordelta en in de monding van de Westerschelde (Troost et al., 2017). Uit Troost et al. (2021) blijkt dat het bestand zich gestaag heeft uitgebreid in de Oosterschelde tot een omvang van 12,7 miljoen $\mathrm{kg}$ versgewicht in het voorjaar van 2020 . Het kokkelbestand in de Oosterschelde was in dat voorjaar 33,7 miljoen $\mathrm{kg}$ versgewicht. Hieruit blijkt dat de Filipijnse tapijtschelp een bestandsomvang heeft bereikt die iets minder dan de helft is van het kokkelbestand in de Oosterschelde. Op kokkels kan worden gevist, mits de voorraad voldoende is voor de scholeksters in het gebied, en de laatste jaren was dit niet het geval. Daarbij vertoonden kokkels in recente jaren grote zomersterfte, waardoor het bestand verder terugloopt (Troost et al., 2021).

Tapijtschelpen kunnen mogelijk beter tegen hete zomers dan kokkels, en slechter tegen koude winters, en zouden, gezien de voortgaande opwarming, de functie van de kokkel in het ecosysteem over te gaan kunnen nemen, zowel als voedsel voor scholeksters als voor de visserij. Binnen het ecosysteem van het (inter)getijdengebied, met zandige tot slikkige bodems, bezetten deze tapijtschelpen ongeveer dezelfde ecologische niche als de inheemse kokkel (Foekema et al., 2014). Ook al lijkt er nog geen directe concurrentie (om ruimte, voedsel) tussen deze soorten te bestaan (Troost, 2021), het ligt wel voor de hand dat concurrentie op enig moment zal gaan optreden (Jung et al., 2020) en mogelijk gaat de Filipijnse tapijtschelp, als meer zuidelijke soort, geholpen door verdere opwarming, deze concurrentiestrijd winnen van de kokkel. Binnen het ecosysteem blijft de "functie van de kokkel" dan behouden, ook al zou de kokkel zelf verdwijnen, iets dat niet noodzakelijkerwijs een slecht scenario is voor bijvoorbeeld schelpdier-etende vogels (Baptist, 2021; Beukhof et al., 2021). Dat deze "vervanging" een reëel scenario is, moge blijken uit de reeks van zomersterftes onder de kokkels in de Oosterschelde en in de Waddenzee (Troost \& Van Asch, 2018; Philippart, 2018) en uit het feit dat de Filipijnse tapijtschelp de lokale (brakwater)kokkel Cerastoderma glaucum al heeft vervangen in de Lagune van Venetië, waar deze tapijtschelp al langer voorkomt (Caldow et al., 2007).

\subsection{Vogels en hun voedselaanbod}

Het voedselaanbod voor schelpdier-etende vogels varieert, door groei en sterfte van de schelpdieren, seizoenale variaties in de vleesinhoud van deze schelpdieren, -vaak aanzienlijke- jaar op jaar variatie in de hoeveelheden en lengteverdelingen van de schelpdieren en door het uitputten van bestanden door de vogels zelf en door de schelpdiervisserij. Een van de bronnen van variatie in het voedselaanbod is een wisselende samenstelling van de verschillende soorten schelpdieren in de bodem. Concurrentieverhoudingen kunnen veranderen, waardoor de ene soort het in een bepaald jaar beter doet dan andere, en het succes van de broedval is bij alle soorten sterk wisselend, iets dat kan doorwerken in de jaren volgend op een bepaalde broedval. Een andere manier waarop het spectrum aan prooisoorten, en dus het voedselaanbod voor vogels zich kan wijzigen, is door het binnendringen van exoten, die enerzijds geschikt aanvullend voedsel kunnen vormen en anderzijds kunnen concurreren met de klassieke voedselsoorten (Jung et al., 2020). Variatie in het voedselaanbod is van alle tijden en vogels zullen zich hieraan aanpassen. Indien een nieuwe soort geschikt is als voedsel zal deze ook door vogels worden benut. Mogelijk moeten de vogels leren omgaan met nieuwe soorten, zeker vogelsoorten die schelpen niet in hun geheel inslikken, maar eerst open maken alvorens het vlees te consumeren. Voor een nieuwe prooisoort kan een nieuwe techniek nodig zijn.

De introductie van een nieuwe voedselbron, zeker als de nieuwe prooisoort lijkt op bestaande soorten en talrijk voorkomt, wordt in veel gevallen gevolgd door predatie. In het geval van (tweekleppige) schelpdieren kunnen bijvoorbeeld eenden en steltlopers profiteren. In Nederland zijn hiervan een aantal voorbeelden:

Driehoeksmossel Dreissena polymorpha (en Quaggamossel D. bugensis). Driehoeksmosselen kwamen zeer talrijk voor in IJsselmeer en Markermeer en internationaal belangrijke aantallen duikeenden 
(zoals kuifeenden en toppereenden) leefden in deze wateren vooral van driehoeksmosselen (van Eerden, 1997; de Leeuw, 1997). Meer recent namen de aantallen driehoeksmosselen af, en zo ook de aantallen eenden in deze wateren (Noordhuis et al., 2014).

Amerikaanse zwaardschede Ensis leei (voorheen E. americanus of E. directus geheten). Deze soort kwam vermoedelijk via geloosd ballastwater terecht in de Duitse Waddenzee in 1979, waarbij al snel door scholeksters werd gegeten (Swennen et al., 1985). Vervolgens bleek dat ook zwarte zee-eenden en eidereenden in de Noordzeekustzone van Denemarken tot in België (Swennen \& Duiven, 1989; Leopold \& Wolf, 2003; Freudendahl \& Jensen, 2006; Leopold et al., 2007; Skov et al., 2008; Tulp et al., 2010; Houziaux et al., 2011; Schwemmer et al., 2019) deze soort eten. Mesheften zijn sterk afwijkend van vorm vergeleken met de klassieke prooisoorten van schelpdier-etende eenden. Deze vogels slikken in de regel hun prooien in zijn geheel, dus met schelp en al, in en kraken de schelpdieren in de spiermaag., Het inslikken van zeker de grotere mesheften kan hierdoor gevaarlijk zijn voor de eenden (Swennen \& Duiven, 1989). Desondanks heeft het bestand van deze mesheften zich ontwikkeld tot een belangrijke voedselbron, voor eenden, scholeksters en, vooral bij massale aanspoelingen op stranden, ook voor bijvoorbeeld meeuwen (Cadée, 2000, 2001). Dat deze mesheften belangrijk bijdragen aan de overleving van bijvoorbeeld eidereenden in de Waddenzee kwam aan het licht in de winter van 2005/2006. De beschikbare hoeveelheid mossel- en kokkelvlees was in die winter erg laag, zodat gevreesd werd voor massasterfte onder eiders, iets dat in eerdere winters bij vergelijkbaar lage beschikbaarheid van de klassieke prooisoorten ook was gebeurd (Camphuysen et al., 2002). Massasterfte onder de eiders bleef echter uit, vermoedelijk omdat deze eenden zich konden redden met de beschikbare hoeveelheid mesheften (Ens et al., 2016). Ook zwarte zee-eenden lijken positief te reageren op concentraties van mesheften (Leopold et al., 2014).

Er zijn echter ook invasieve schelpdieren, waar vogels niet of nauwelijks profijt van hebben, zoals de Japanse oester Magallana gigas (voorheen: Crassostrea gigas) en het muiltje Crepidula fornicata, dus er is geen garantie dat een introductie ook profijtelijk is voor vogels. Oesters en muiltjes hebben met elkaar gemeen dat ze qua vorm sterk afwijken van de voedselsoorten waar de vogels in Nederland aan gewend zijn. Voor de Filipijnse tapijtschelp ligt dit wellicht anders. Deze komt qua formaat en levenswijze (ondiep ingegraven in het sediment) overeen met bijvoorbeeld de kokkel.

Een invasieve soort kan geschikt voedsel voor vogels opleveren, en zo een bijdrage leveren aan de fitness / overleving / reproductie van de betreffende soort als:

1. De soort in hoge dichtheden voorkomt

2. De soort eetbaar (te openen of in te slikken) is

3. De soort voor de vogels bereikbaar is, dus bijvoorbeeld niet op te grote dieptes onder water of in het sediment voorkomt, of te sterk aan de bodem of aan harde structuren is vastgehecht

4. De soort met voldoende profijt (opbrengst per tijd of opbrengst per inspanning) te eten is

5. Geen gevaarlijke nevenfauna in zich heeft, zoals voor vogels dodelijke parasieten.

6. De soort niet giftig is.

Met parasieten geïnfecteerde schelpdieren (Hulscher, 1982), of schelpdieren die zich wapenen tegen predatie door gifstoffen in hun weefsels (van Gils et al., 2013), kunnen minder attractief zijn voor vogels. Er zijn echter geen aanwijzingen dat deze zaken spelen bij de Filipijnse tapijtschelp: in Poole Harbour aten scholeksters deze nieuwkomer in toenemende mate (Caldow et al., 2007). Deze succesvolle invasieve exoot bevindt zich in Nederland nog in de fase van de snelle groei van het bestand. Een volgende fase is er vermoedelijk een van forse bestandsschommelingen, gevolgd door stabilisatie op een lager niveau dan het ooit bereikte piekniveau. De nieuwe soort krijgt steeds meer te maken met predatoren en parasieten en komt zo in evenwicht met zijn omgeving (Jung et al., 2020). Vermoedelijk is de belasting met parasieten in de groeifase van de populatie dus nog gering en zullen predatoren als de scholekster hier nog weinig last van ondervinden. Uit het feit dat Filipijnse tapijtschelpen veelvuldig voor menselijke consumptie worden gekweekt, opgevist en gegeten kunnen we ook opmaken dat parasitaire infecties, of gifstoffen in het vlees, bij deze soort van geen belang zijn. 


\section{Kennisvraag}

De vraag ligt voor of Filipijnse tapijtschelpen in de Oosterschelde kunnen bijdragen aan voedselvoorziening van scholeksters en of hierdoor de rekenregels voor de voedselreservering kunnen worden aangepast.

Om deze vraag nader te adresseren heeft LNV vijf kennisvragen gesteld:

A. Is uit bestaande literatuur bekend of (en in welke mate) Filipijnse tapijtschelpen een volwaardige (en/of aanvullende) voedselbron kunnen zijn?

B. Welke onderbouwing is daarbij gevonden en welke noodzakelijke kennis ontbreekt eventueel?

C. Uitgaande van een minimummaat van kokkels van $21 \mathrm{~mm}$ : is op basis van 'expert judgement' een minimummaat voor visserij te adviseren van tapijtschelpen?

D. Voor welke vogelsoorten kunnen Filipijnse tapijtschelpen in de Oosterschelde en het Grevelingenmeer een volwaardige en/of aanvullende voedselbron vormen? Daarbij wordt ook meegenomen in welke mate deze soorten gebruik maken van de Oosterschelde en het Grevelingenmeer in vergelijking met andere Nederlandse (kust)wateren.

E. Indien tapijtschelpen inderdaad als volwaardige alternatieve (en/of aanvullende) voedselbron aangemerkt kunnen worden, welke consequenties zou dit kunnen hebben voor de voedselreservering voor scholeksters in de Oosterschelde?

In dit rapport gaan we in op genoemde vragen. Dit wordt gedaan middels bureau-onderzoek en een klein deel veld- en labwerk. 


\section{Methoden}

De relatie tussen met name scholeksters en andere vogels en de Filipijnse tapijtschelp is onderzocht door literatuuronderzoek en ingeschat middels expert judgement.

Voor de vergelijking van kokkels en Filipijnse tapijtschelpen zijn extra metingen uitgevoerd gedurende de WOT bestandsopname in het voorjaar van 2021. Hierbij zijn 50 Filipijnse tapijtschelpen verzameld tijdens de survey in de Oosterschelde, 50 in het Grevelingenmeer en 50 in het Veerse Meer. Aan deze dieren zijn de volgende metingen uitgevoerd:

- $\quad$ versgewicht (schelp, vlees en zeewater in schelp) in gram

- vleesgewicht in gram na koken, drogen bij $70^{\circ} \mathrm{C}$ en verassen bij $540^{\circ} \mathrm{C}$

- $\quad$ schelpgewicht in gram na drogen bij $70^{\circ} \mathrm{C}$.

- lengte, breedte en hoogte van de schelp in mm (Figuur 3).

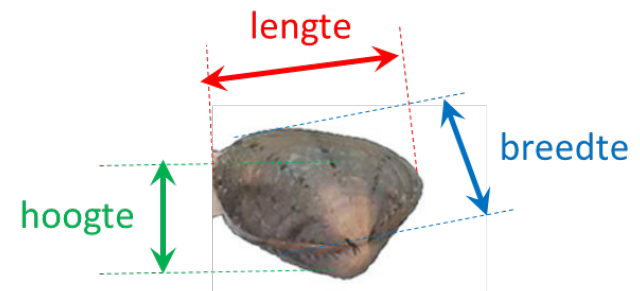

Figuur 3. Lengte, breedte en hoogte zoals gemeten bij de kokkels en Filipijnse tapijtschelpen.

Voor kokkels is gebruik gemaakt van een dataset uit 2002 die is verzameld door M. Alluno Brucia (RIVO, ongepubliceerde data). In het voorjaar van 2002 zijn 414 kokkels verzameld in de kom van de Oosterschelde. Het vleesgewicht na drogen bij $70^{\circ} \mathrm{C}$ (drooggewicht) en verassen bij $520^{\circ} \mathrm{C}$ (as-vrij drooggewicht) is bepaald, almede het schelpgewicht gedroogd bij $70^{\circ} \mathrm{C}$ en de lengte, breedte en hoogte van de schelp. De lengtes van de kokkels zijn omgerekend naar versgewicht m.b.v. de volgende formule uit Kamermans et al. (2003): versgewicht in $\mathrm{mg}=0.7280 *(\text { lengte in } \mathrm{mm})^{2.8108}$

Het versgewicht is de basis van de kokkelbestandsberekening (Troost et al., 2021). Het bestand per 1 september wordt berekend volgens methoden beschreven in Kamermans et al. (2003). Daar wordt bij de omrekening van versgewichten naar hoeveelheden kokkelvlees uitgegaan van een gemiddeld gekookt vleespercentage van 15\% (Van Stralen, 1990). Dit percentage is berekend voor tapijtschelpen door het gekookte vleesgewicht te delen door het versgewicht. Voor eenden die de schelp in hun maag kraken is de verhouding tussen schelp- en vleesgewicht belangrijk. Dit is berekend door het asvrij drooggewicht van het vlees te delen door het schelpgewicht.

Verder worden alleen kokkelvoorkomens met dichtheden boven de 50 per $\mathrm{m}^{2}$ in de berekening van het oogstbare bestand betrokken (zie ook Bult en Kesteloo, 2002). Dit is gebaseerd op de aanname dat dichtheden lager dan 50 per $\mathrm{m}^{2}$ niet profijtelijk zijn voor scholeksters, o.a. in verband met een te lange zoektijd (Ens et al., 2004). Recentelijk is echter een studie verschenen die laat zien dat ook lagere dichtheden profijtelijk kunnen zijn (Goss-Custard et al., 2020). Het bestand van kokkels bij dichtheden hoger dan 50 kokkels per $\mathrm{m}^{2}$ wordt in de huidige voedselreservering gezien als 'oogstbaar' voor scholeksters. Voor de vergelijking tussen kokkels en Filipijnse tapijtschelpen zijn gebieden met dichtheden hoger dan 50 individuen per $\mathrm{m}^{2}$ in 2020 voor beide soorten vergeleken.

Daarnaast is nagegaan waar de minimummaat voor kokkels op is gebaseerd, welk doel deze dient en wat dit betekent voor de tapijtschelp.

En tenslotte is in kaart gebracht welke specifieke kennis ontbreekt en hoe deze verworven kan worden. 


\section{Resultaten en discussie}

\subsection{Vergelijking kokkels en tapijtschelpen}

\subsubsection{Morfometrie kokkels en Filipijnse tapijtschelpen}

De analyse van de bemonsterde kokkels en tapijtschelpen laat zien dat tapijtschelpen groter zijn dan kokkels van dezelfde leeftijd en dat ze ook een grotere lengte kunnen bereiken (Fig. 4). Daarnaast zijn voor beide soorten twee cohorten te identificeren: 10-15 mm kokkels en 16-20 mm tapijtschelpen zijn waarschijnlijk eenjarigen en 21-25 mm kokkels en 26-30 mm kokkels zijn waarschijnlijk twee jaar oud.

De minimummaat van kokkels voor visserij is $21 \mathrm{~mm}$ schelplengte. Deze maat is gebaseerd op het vleesgehalte dat nog verkoopbaar is (pers. mededeling J. Holstein). De minimummaat spaart daarnaast de eenjarigen. Deze groep plant zich over het algemeen nog niet voort (Iglesias \& Navarro, 1991) en kan dan opgroeien en een keer paaien in het voorjaar voordat ze wordt opgevist in het najaar. Ook voor tapijtschelpen geldt dat de eenjarigen kleiner zijn dan $21 \mathrm{~mm}$. Bij de tapijtschelp zien we een lange "staart" van grotere lengtes die suggereert dat er ook relatief veel oudere tapijtschelpen voorkomen dan die van 2 jaar.

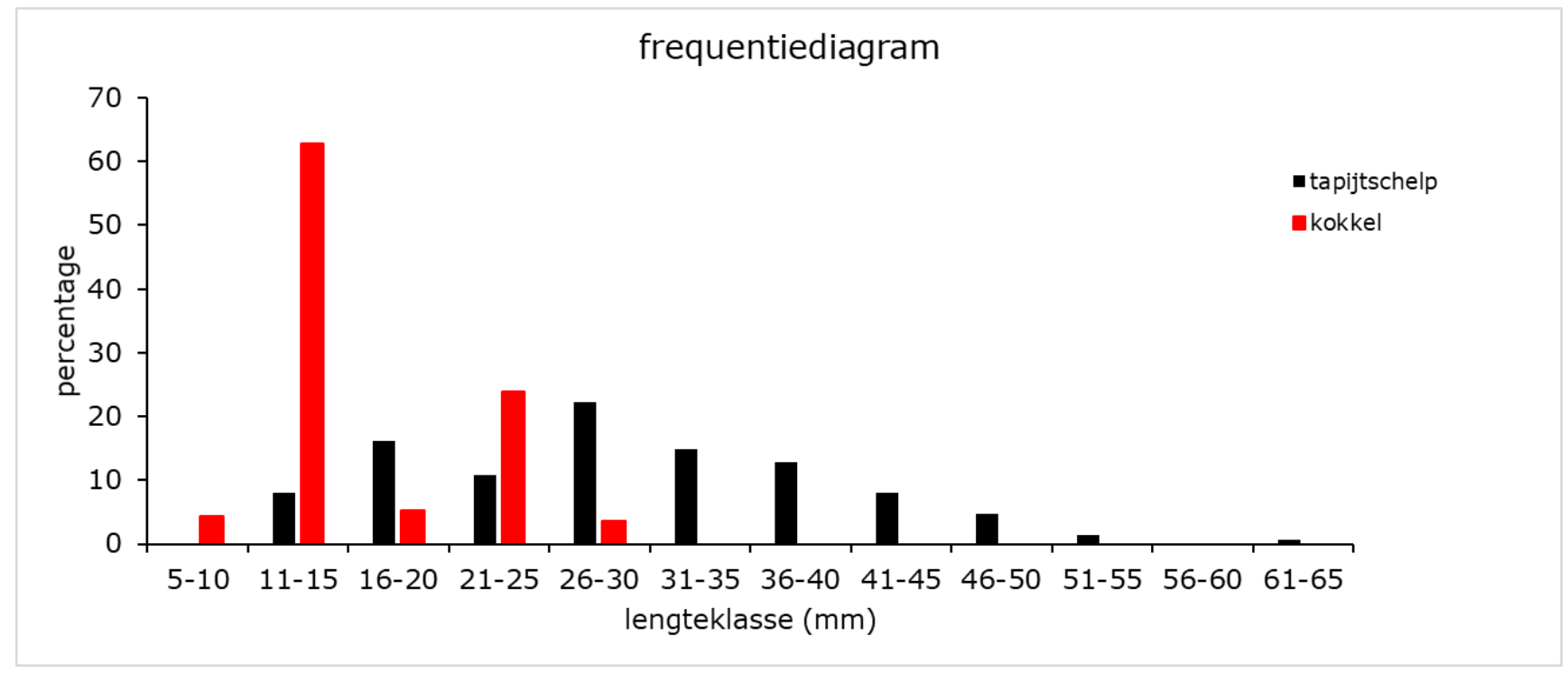

Figuur 4. Lengteklasse verdeling van kokkels (rood) en tapijtschelpen (zwart).

Kokkels zijn bij dezelfde lengte iets hoger dan tapijtschelpen (Fig. 5). 


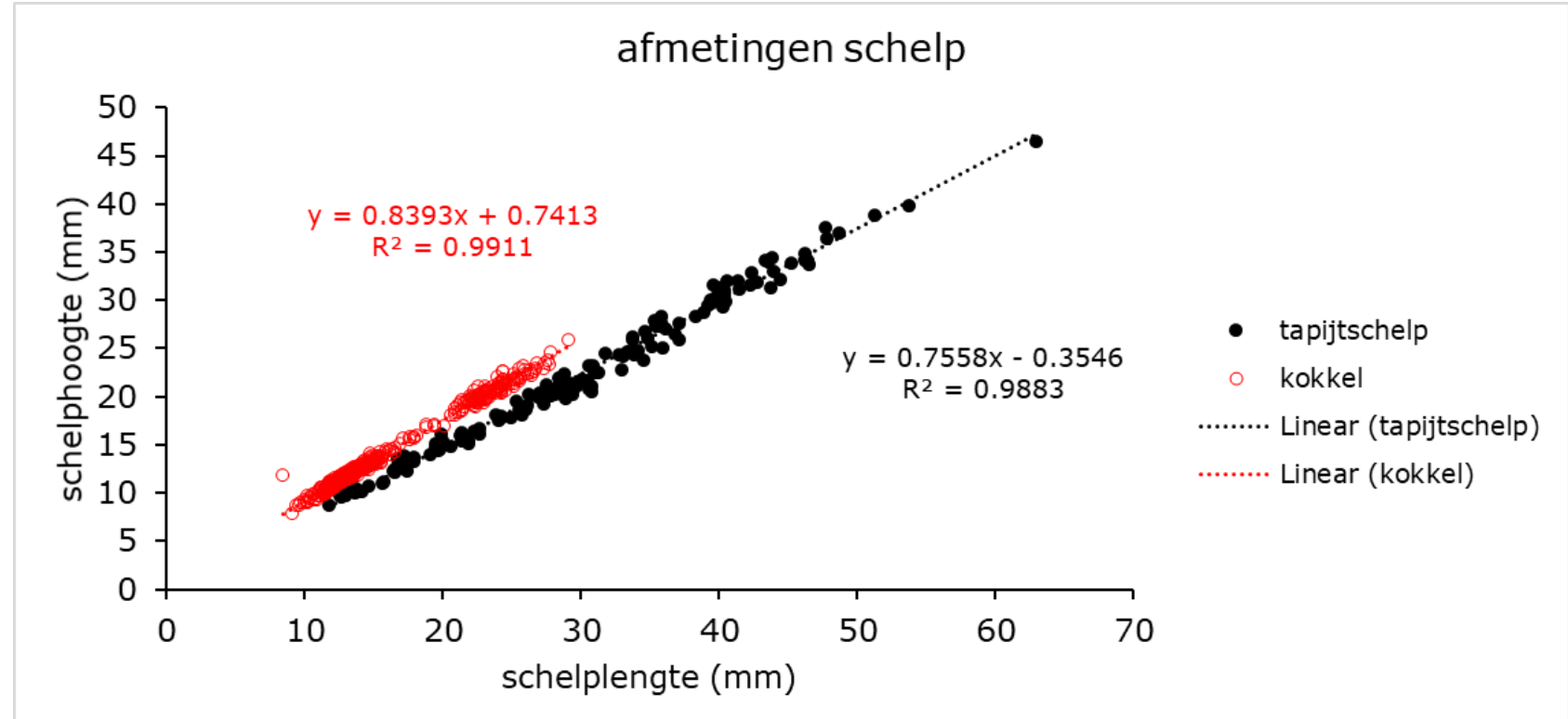

Figuur 5. Relatie tussen schelplengte en schelphoogte van kokkels (rood) en tapijtschelpen (zwart).

Bij de verhouding tussen schelpbreedte en schelplengte is te zien dat kokkels bij een zelfde schelplengte iets minder breed zijn dan tapijtschelpen, maar de verschillen zijn klein (Fig. 6).

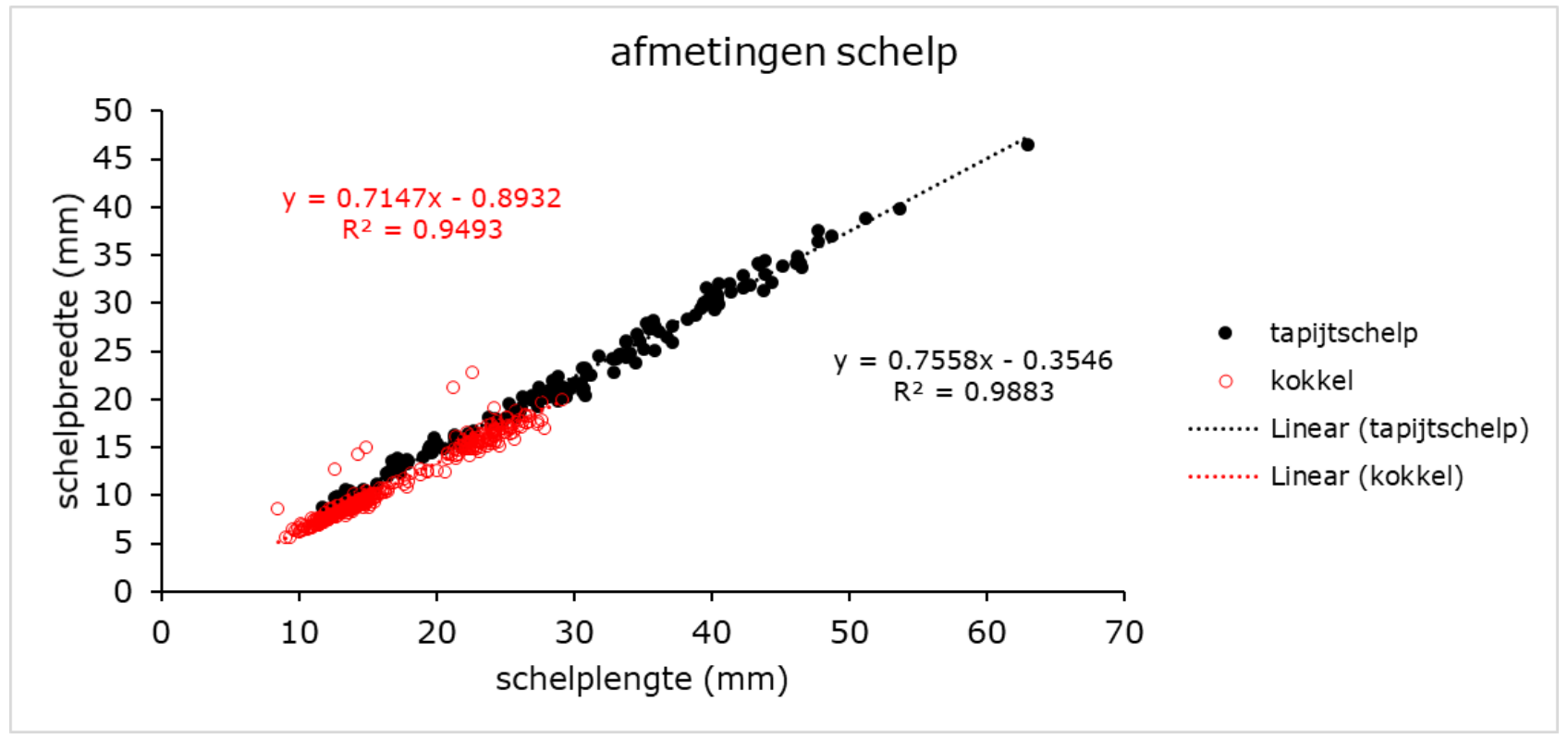

Figuur 6. Relatie tussen schelplengte en schelpbreedte van kokkels (rood) en tapijtschelpen (zwart).

Het verband tussen het versgewicht van het levende dier en de schelplengte is zeer vergelijkbaar voor beide soorten, maar ook hier is weer duidelijk te zien dat tapijtschelpen veel grotere formaten bereiken dan kokkels (Fig. 7). 


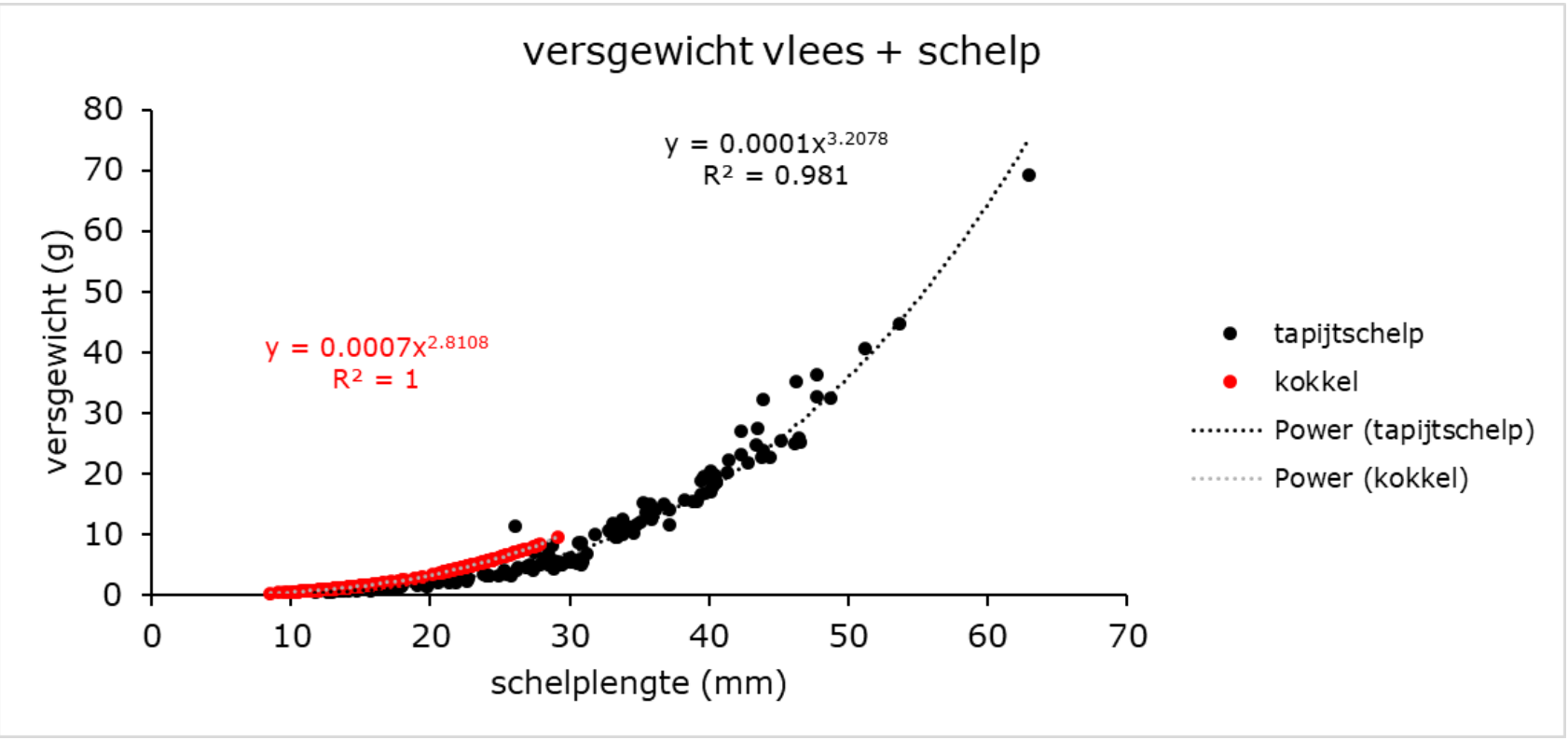

Figuur 7. Relatie tussen schelplengte en versgewicht van kokkels (rood) en tapijtschelpen (zwart). De versgewicht waarden voor kokkels zijn berekend uit de lengtes volgens Kamermans et al. (2003)

Bij de kokkelbestandsberekening wordt ervan uitgegaan dat 15\% van het versgewicht bestaat uit kokkelvlees (Van Stralen, 1990). Bij tapijtschelpen is deze verhouding 16,89\% 5,60, wat erg vergelijkbaar is.

Ook de relatie tussen het as-vrij drooggewicht van het vlees en de schelplengte is vergelijkbaar voor kokkels en tapijtschelpen (Fig. 8).

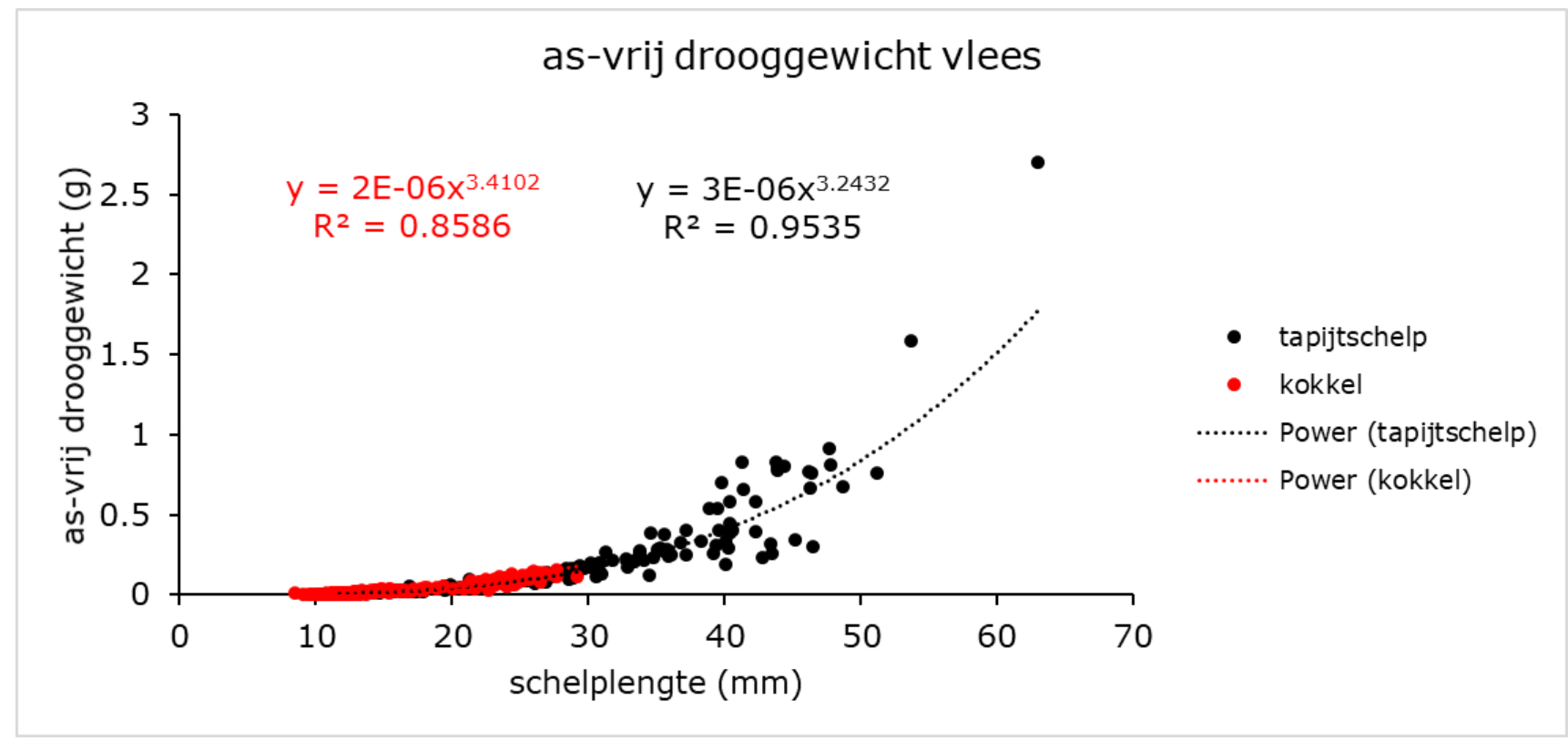

Figuur 8. Relatie tussen schelplengte en as-vrij drooggewicht van het vlees van kokkels (rood) en tapijtschelpen (zwart).

Het verband tussen drooggewicht van de schelp en schelplengte is vergelijkbaar voor kokkels en tapijtschelpen (Fig. 9). 


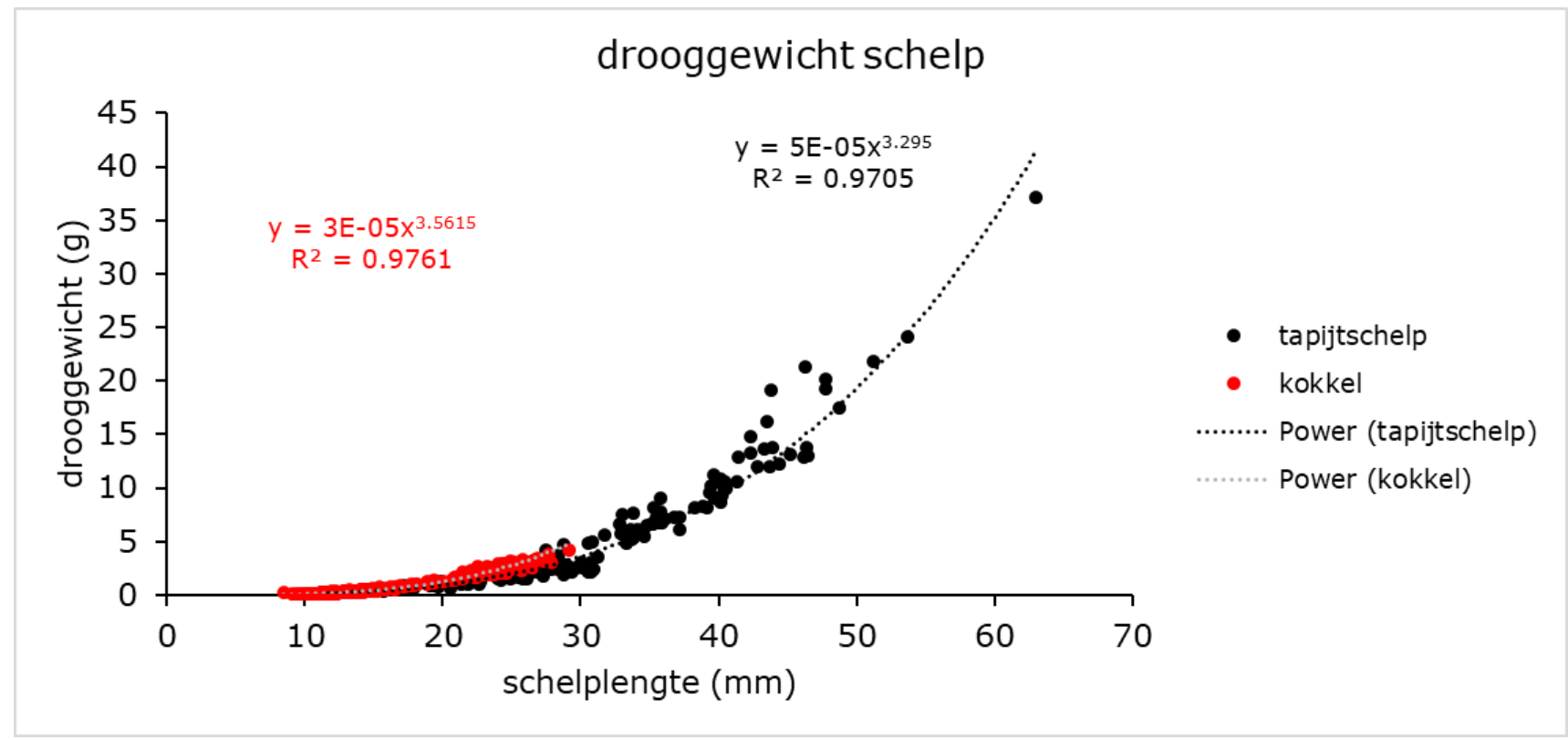

Figuur 9. Relatie tussen schelplengte en het drooggewicht van de schelp van kokkels (rood) en tapijtschelpen (zwart).

De verhouding tussen as-vrij drooggewicht van het vlees en drooggewicht van de schelp is ook vergelijkbaar voor kokkels met gemiddeld 4,36\% $\pm 1,47$ en tapijtschelpen met gemiddeld 4,70\% $\pm 1,51$.

Samenvattend kan worden gesteld dat kokkels en tapijtschelpen een vergelijkbare morfometrie laten zien. Het belangrijkste verschil is de range in afmetingen, die groter is voor tapijtschelpen.

\subsubsection{Dichtheid kokkels en tapijtschelpen in de Oosterschelde}

Zowel kokkels als tapijtschelpen komen voor in dichtheden boven 50 per $\mathrm{m}^{2}$ (Figuur 10). De gebieden waar tapijtschelpen hoge dichtheden bereiken, overlappen met de gebieden waar veel kokkels voorkomen. 

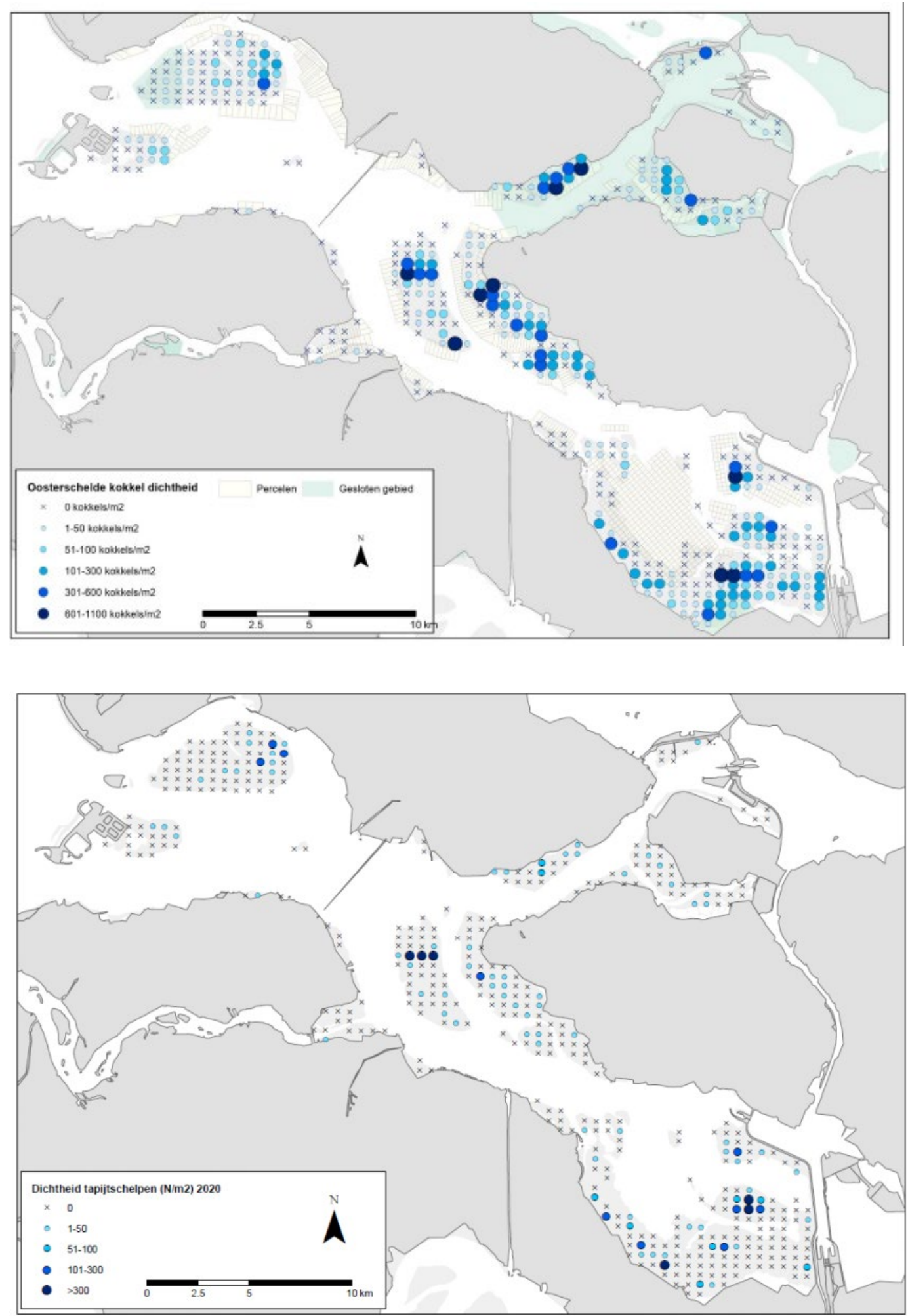

Figuur 10. Dichtheid van kokkels (boven) en tapijtschelpen (onder) in de Oosterschelde in 2020. Bron: Troost et al. (2021).

\subsubsection{Ingraafdiepte kokkels en tapijtschelpen}

Ingraafdiepte van de kokkel varieert van 1-2 cm (Zwarts \& Wanink, 1993). Die van tapijtschelpen is met 2-4 cm iets dieper Foekema et al., 2014), maar beiden vallen binnen de reikwijdte van scholeksters (Zwarts \& Wanink, 1993). 


\subsubsection{Temperatuurtolerantie van kokkels en tapijtschelpen}

Bij kokkels in Portugal neemt de sterfte sterk toe boven een temperatuur van $26^{\circ} \mathrm{C}$ en boven $32^{\circ} \mathrm{C}$ is de sterfte $100 \%$ (Verdelhos et al., 2015). Er zijn echter aanwijzingen dat kokkels zowel regionale verschillen als seizoensverschillen vertonen (Wilson \& Elkaim, 1997). Tapijtschelpen laten sterfte zien boven $28^{\circ} \mathrm{C}$ (Lopez-Joven et al, 2018). Tapijtschelpen tolereren dus hogere temperaturen dan kokkels. Gewenning maakt dat de soort steeds beter overleeft bij hogere temperaturen. Shin et al. (2000) toonden aan dat tapijtschelpen die een gewenningsperiode hadden meegemaakt bij $25^{\circ} \mathrm{C}$ een temperatuur van $37^{\circ} \mathrm{C}$ nog konden tolereren terwijl tapijtschelpen uit $18^{\circ} \mathrm{C}$ een maximum temperatuur van $36^{\circ} \mathrm{C}$ tolereerden.

De minimum temperatuur waar Filipijnse tapijtschelpen in hun oorspronkelijke range in Azië aan worden blootgesteld ligt rond de $9^{\circ} \mathrm{C}$ (Kurihara et al., 2018). En er zijn aanwijzingen dat de soort koude winters in noord China niet overleeft (Nie et al., 2016). De tapijtschelp heeft echter de winter van 2020/2021 in de Oosterschelde overleefd (Troost, 2021) dus wellicht heeft de soort zich sinds de vestiging in Europa al weten aan te passen aan de omstandigheden hier. Het is onbekend bij welke minimum temperatuur hier geen overleving meer plaatsvindt.

\subsection{Filipijnse tapijtschelpen als voedsel voor vogels in de Oosterschelde en het Grevelingenmeer}

In de Oosterschelde heeft de Filipijnse tapijtschelp in korte tijd een aanzienlijke biomassa bereikt en hetzelfde geldt voor een andere nieuwkomer, de Japanse oester (Troost et al., 2021). Toch laat een omvangrijke studie naar de draagkracht van het systeem zien dat alle schelpdieren samen in de Oosterschelde niet de productie van fytoplankton zodanig negatief beïnvloeden dat er sprake is van overbegrazing (Jansen et al., 2019). De twee nieuwkomers hebben zich kunnen vestigen en uitbreiden zonder dat dit ten koste is gegaan van de meest prominente schelpdiersoort in de Oosterschele in termen van graasdruk op het fytoplankton: de mossel. De vleesinhoud van mosselen niet gedaald als gevolg van de beide introducties. Wel is het bestand aan kokkels in de Oosterschelde gedaald, en zo ook het bestand aan oesters, beide sinds 2010, dus terwijl het bestand van tapijtschelpen in de Oosterschelde groeide, daalden de bestanden van kokkels en oesters, maar niet het vleesgehalte van de mosselen. Het is dus niet uitgesloten dat de groei van het bestand aan tapijtschelpen (deels) ten koste is gegaan van het bestand aan kokkels en oesters, al zijn er ook andere verklaringen dan competitie tussen deze soorten te geven voor de afname van kokkels (zomersterfte) en oesters (opkomst van de oesterboorder en van het oester herpesvirus; actief wegvissen) (Jansen et al., 2019). Voor schelpdier-etende vogels, als de scholekster, kan, ook bij concurrentie tussen tapijtschelpen, kokkels en oesters, de balans positief zijn. Oesters kunnen door scholeksters niet of nauwelijks worden gegeten, dus een verschuiving van oester- naar tapijtschelpbiomassa is te zien als "winst" voor de vogels. Of een verschuiving van kokkels naar tapijtschelpen positief, negatief of neutraal uitpakt voor de vogels hangt af van relatieve efficiëntie waarmee de vogels de beide soorten kunnen eten (veelal uitgedrukt in $\mathrm{mg}$ vlees opgenomen per seconde foerageren) en van de vraag of de vogels tapijtschelpen (hebben leren) eten en in welke mate ze dit zijn gaan doen.

\subsubsection{Kennisvragen A en B: kan de Filipijnse tapijtschelp een volwaardige (en/of aanvullende) voedselbron zijn, welke evidentie is hiervoor en welke kennis ontbreekt nog?}

De relatieve profijtelijkheid van tapijtschelpen, bijvoorbeeld ten opzichte van de kokkel, zal afhangen van de dichtheid aan tapijtschelpen, de ingraafdiepte, de hardheid van de schelp (voor scholeksters die de schelpen open "hameren" om bij het vlees te komen) en de vlees/schelp verhouding (voor soorten die schelpdieren in hun geheel inslikken in kraken in de maag). In Nederland is geen onderzoek gedaan naar de rol van de Filipijnse tapijtschelp als prooisoort voor vogels. Er is echter wel één studie gedaan in Engeland (Caldow et al., 2007), naar het eten van deze tapijtschelpen door scholeksters, in Poole Harbour, aan de zuidkust van Engeland. Bij gebrek aan studies in Nederlandse getijdengebieden, moeten op deze studie terugvallen om in te schatten hoe scholeksters met deze 
nieuwe voedselsoort om zouden kunnen gaan. Deze Britse studie vond plaats in het niet-broedseizoen, van augustus 2004 tot maart 2005. Foeragerende scholeksters op drooggevallen platen werden gevolgd om te zien of ze kokkels of tapijtschelpen aten, en zo ja, met welke efficiëntie. Er bleken vogels te zijn die zich specialiseerden op tapijtschelpen, of op kokkels, of die een gemengd dieet hadden of zich specialiseerden op andere prooien (strandgapers, mosselen, nonnetjes, of wormen). De grootte van de gegeten prooien werd geschat, omgerekend naar vleesinhoud op basis van een vooraf bepaalde schelpgrootte-vleesinhoud relatie, en doorgerekend naar mg vlees, opgenomen per seconde foerageren (uitgedrukt in as-vrij drooggewicht; mg AFDW/seconde).

Een eerste bevinding uit deze studie was dat het percentage vogels dat zich specialiseerde op tapijtschelpen, of die tapijtschelpen naast andere prooien aten, toenam gedurende de studieperiode. Aangezien er slechts gedurende één winter werd geobserveerd, is niet duidelijk of dit een normaal (jaarlijks terugkerend) seizoenseffect is, of dat de scholeksters nog aan het leren waren om tapijtschelpen te eten. Aan het eind van de winter was circa $20 \%$ van de scholeksters in het eten van tapijtschelpen gespecialiseerd en nog eens ongeveer $50 \%$ had tapijtschelpen als nevenprooi in hun dieet.

Een tweede bevinding was dat de scholeksters alle maten tapijtschelpen aten die in de wadbodem voorradig waren, zonder noemenswaardige grootteselectie. Waargenomen prooien waren 16-50 mm groot, met de aantekening dat grotere tapijtschelpen destijds (nog) niet aanwezig waren (ook in de Oosterschelde zijn deze nog erg zeldzaam, figuur 3) en dat de vogels wel kleinere prooien aten, maar dat deze niet op soort gebracht konden worden door de waarnemers. Het is dus niet uitgesloten dat het groottespectrum van gegeten tapijtschelpen nog iets breder is dan waargenomen.

Een derde observatie was dat de scholeksters die zich op het eten van tapijtschelpen specialiseerden, minstens even efficiënt waren (uitgedrukt in $\mathrm{mg} \mathrm{AFDW/s} \mathrm{dat} \mathrm{ze} \mathrm{tijdens} \mathrm{het} \mathrm{foerageren} \mathrm{binnen} \mathrm{kregen)}$ als de kokkelspecialisten. Een nadere literatuurstudie naar gemeten foerageerefficiënties bij scholeksters liet zien dat de tapijtschelpeters ook niet onder deden voor specialisten op mosselen, platte slijkgapers of nonnetjes. Hierbij was de gemeten dichtheid van Filipijnse tapijtschelpen in Poole Harbour slechts gemiddeld 5 per $\mathrm{m}^{2}$.

Een vierde bevinding (model uitkomst) was dat de komst van de Filipijnse tapijtschelp in Poole Harbour bijdroeg aan de overleving gedurende de winter van de lokale populatie scholeksters.

De conclusie van deze Britse studie is dus dat de Filipijnse tapijtschelp een volwaardige (en/of aanvullende) voedselbron kan zijn voor scholeksters. Daarbij groeien tapijtschelpen sneller dan kokkels, bereiken ze een grotere lengte en bevatten ze dus meer vlees dan kokkels, waardoor ze bij gelijke dichtheden wellicht zelfs profijtelijker zijn dan kokkels.

Ontbrekende kennis: In Nederland is geen onderzoek gedaan naar het foerageren van scholeksters op tapijtschelpen, dus in feite is onbekend of deze vogels ook in Nederland (al) tapijtschelpen eten; zo ja, wanneer ze daarmee zijn begonnen en of ze thans nog in een leercurve zitten; welk deel van de scholeksters tapijtschelpen eten; of er onderscheid is naar leeftijd, geslacht en snavelmaat (zie: Swennen et al., 1983; van de Pol et al., 2009), met andere woorden of alle scholeksters even goed in staat zijn tapijtschelpen te eten of dat dit slechts is weggelegd voor een deel van de populatie; bij welke dichtheden de vogels op deze nieuwe voedselbron efficiënt kunnen foerageren? Wat de bijdrage van de Filipijnse tapijtschelp is aan het dieet en de overleving van scholeksters in Nederland is dus onbekend.

\subsubsection{Kennisvraag C: Uitgaande van een minimummaat van kokkels van $21 \mathrm{~mm}$ : is op basis van 'expert judgement' een minimummaat voor visserij te adviseren van tapijtschelpen?}

In de mechanische kokkelvisserij is de afstand tussen de spijlen in de molens minimaal $15 \mathrm{~mm}$ omdat dit de schelphoogte is die bij de $21 \mathrm{~mm}$ schelplengte hoort (pers. mededeling $\mathrm{M}$. van Stralen en B. Keus). De verhouding tussen schelphoogte en schelplengte is niet helemaal gelijk voor beide soorten schelpdieren (Fig. 5). Bij eenzelfde lengte zijn kokkels iets hoger. Bij 15 mm hoogte zijn de kokkels uit 
deze analyse $17 \mathrm{~mm}$ lang en tapijtschelpen $21 \mathrm{~mm}$. Dit betekent dat voor tapijtschelpen dezelfde minimumwaarde voor schelplengte $(21 \mathrm{~mm})$ en spijlafstand $(15 \mathrm{~mm})$ kan worden aangehouden.

Ontbrekende kennis: De minimummaat voor kokkels is gebaseerd op de verkoopbaarheid van het product. Het Ministerie van LNV gaf in 1998 aan, in de Structuurnota Zee- en kustvisserij, dat: "[Kokkel]banken die overwegend bestaan uit nul-jarige kokkels worden door het visplan [van de kokkelsector] gesloten". Jonge kokkels worden dus al langer door de visserij gespaard, maar of dit nu samenhangt met een veronderstelde voorkeur van de vogels voor kleine kokkels, of om de visserij ook voor volgende jaren veilig te stellen, wordt niet vermeld. In het geval van de Filipijnse tapijtschelp geldt een extra complicatie: deze soort geldt als een invasieve exoot. De vraag is dan of het opportuun is om een dergelijke nieuwkomer te sparen. Deze discussie is nog niet gevoerd. In haar beleidsnota meldt Het Ministerie van LNV over exoten in algemene zin: "Preventie, bestrijding of beheersing van exoten hoeft slechts plaats te vinden wanneer geïntroduceerde soorten een reële dreiging vormen. Vaak is dit echter lastig van te voren te bepalen en is het beter om te voorkomen dat exoten in de natuur terecht komen en als dat niet gelukt is kunnen exoten het best verwijderd worden als de populaties nog klein en beheersbaar zijn". Foekema et al 2014 hebben een risk assessment uitgevoerd en gaven de soort een ISEIA score van 10 wat duidt op een gemiddeld risico. Het risico betreft het effect op de draagkracht van de Oosterschelde. Het stadium van een kleine beheersbare populatie zijn we al gepasseerd, dus bestrijding is niet meer aan de orde. Bovendien heeft de Filipijnse tapijtschelp in potentie twee nuttige functies: voor de visserij en voor de vogels. Hiermee kan deze nieuwkomer, wellicht op termijn, deze functies overnemen van de inheemse kokkel, mocht deze het door de toenemende omgevingstemperaturen, niet redden.

\subsubsection{Kennisvraag D: Voor welke vogelsoorten kunnen Filipijnse tapijtschelpen in de Oosterschelde en het Grevelingenmeer een volwaardige en/of aanvullende voedselbron vormen? Daarbij wordt ook meegenomen in welke mate deze soorten gebruik maken van de Oosterschelde en het Grevelingenmeer in vergelijking met andere Nederlandse (kust)wateren.}

Schelpdieren worden door vier groepen van vogels gegeten: eenden, steltlopers, meeuwen en kraaien. Kraaien eten schelpdieren slechts bij uitzondering, vooral dode of stervende exemplaren in de aanspoelzone en nooit in groten getale, deze groep laten we buiten beschouwing. Meeuwen en dan vooral zilvermeeuwen hebben relatief veel schelpdieren op hun menu staan (Leopold et al., 2004). Meeuwen kunnen alleen schelpdieren eten op drooggevallen platen, of in de aanspoelzone als er sprake is van sterfte. Van de steltlopers kan alleen de scholekster de grotere (> ca $1 \mathrm{~cm}$ ) exemplaren van tapijtschelpen eten. Broedjes kunnen echter door tal van steltlopers worden gegeten, ook al staan deze vooral bekend als wormen eters (Leopold et al., 2004). Caldow et al. (2007) noemen als kandidaten: wulp, grutto, rosse grutto, kanoet en zilverplevier. Durell \& Kelly (1990) voegen hier nog de bonte strandloper aan toe en gezien deze lijst mogen we aannemen dat soorten als drieteenstrandloper en steenloper ook wel broedjes van tapijtschelpen kunnen eten. Evenals de meeuwen zijn deze steltlopers aangewezen op laag water als ze op schelpdieren willen foerageren en hetzelfde geldt voor een soort als de bergeend. Ook deze kan alleen kleine exemplaren (broedjes) van tapijtschelpen aan. Enkele soorten duikende eenden, tenslotte, zijn gespecialiseerd in het eten van schelpdieren (eidereend, zwarte en grote zee-eend, topper, kuifeend) en eten naast plantaardig voedsel of vis, ook wel schelpdieren (brilduiker, tafeleend). Van deze eenden zijn vooral de eider en de twee zee-eenden in staat om tapijtschelpen tot een paar cm groot te eten, maar zowel de eider als de zee-eenden zijn in de Zeeuwse Deltawateren erg schaars en de komst van de Filipijnse tapijtschelp is hier voor hen niet relevant.

Schelpdier-etende soorten die hier relevant zijn, dat wil zeggen tamelijk algemeen voorkomen en een Natura 2000-status hebben zijn: scholekster en brilduiker in het Grevelingenmeer (Arts et al., 2019) en bergeend, bonte strandloper, drieteenstrandloper, kanoet, rosse grutto, scholekster, steenloper, wulp en zilverplevier in de Oosterschelde (van Donk et al., 2020). Van deze soorten vertonen zowel de scholekster als de brilduiker een langjarige negatieve trend in beide wateren, en zijn de aantallen van de rosse grutto, kanoet, zilverplevier, steenloper en bonte strandloper in de Oosterschelde min of meer stabiel, terwijl de aantallen van bergeend, wulp en drieteenstrandloper hier zijn toegenomen. 
Soorten die mogelijk broedjes van tapijtschelpen zouden kunnen eten vertonen dus een wisselend beeld, terwijl de scholekster het over een lange reeks van jaren slecht doet in zowel het

Grevelingenmeer als in de Oosterschelde (Arts et al., 2019; van Donk et al., 2020). Of er al meeuwen of bergeenden zijn die de tapijtschelpen als nieuwe voedselbron hebben ontdekt is onbekend, terwijl de specialisten onder de duikende eenden niet in belangrijke aantallen in de Delta (binnen)wateren voorkomen.

Ontbrekende kennis: Het is nog voor geen enkele vogelsoort duidelijk of deze in het Grevelingenmeer of in de Oosterschelde tapijtschelpen eten. Om vast te stellen of Filipijnse tapijtschelpen door vogels in deze gebieden worden gegeten, is dieetonderzoek nodig, hetzij middels gerichte observaties aan foeragerende vogels (conform Caldow et al., 2007), hetzij door prooiresten in uitwerpselen te verzamelen (conform Durell \& Kelly 1990). Dieet van zilvermeeuwen kan ook in de broedkolonies worden gevolgd, aan de hand van uitgebraakt voedsel (conform Camphuysen 2013). In het geval van scholeksters lijkt het ook mogelijk om leeg gegeten, op de platen achtergelaten schelpen van zowel kokkels als tapijtschelpen te verzamelen voor onderzoek.

\subsubsection{Kennisvraag E: Indien tapijtschelpen inderdaad als volwaardige alternatieve (en/of aanvullende) voedselbron aangemerkt kunnen worden, welke consequenties zou dit kunnen hebben voor de voedselreservering voor scholeksters in de Oosterschelde?}

Er zijn drie redenen te geven waarom het zinnig zou zijn om de bestaande regels ten aanzien van de voedselreservering te evalueren en eventueel te herzien:

1. De huidige regel is dat er per scholekster in de Oosterschelde $150 \mathrm{~kg}$ kokkelvlees moet liggen, alvorens op kokkels gevist mag worden, dat kokkels kleiner dan $21 \mathrm{~mm}$ niet mogen worden aangeland en dat kokkels in dichtheden onder de 50 per vierkante meter niet meetellen. Deze regels zijn opgesteld aan de hand van de studie van Rappoldt et al. (2003). De wereld is veranderd: het bestand aan kokkels komt in de meeste jaren niet boven deze grenswaarde (Troost et al., 2021), vertoonde meermalen aanzienlijke zomersterfte (Troost en Van Asch, 2018), tapijtschelpen hebben hun intrede gedaan (Troost al., 2021), het aantal scholeksters is gestaag achteruitgegaan in de Oosterschelde (van Donk et al., 2020). De achterliggende reden van de achteruitgang van scholeksters is niet duidelijk.

2. Bij de rekenmethode van Rappoldt et al. (2003), en bij de suggestie dan kokkels in dichtheden onder de 50 per vierkante meter voor scholeksters niet oogstbaar zouden zijn, zijn onlangs kanttekeningen gemaakt door Goss-Custard \& Stillman (2020); zij stellen een andere rekenmethode voor en geven daarvoor uitgebreid de argumenten.

3. Indien kan worden vastgesteld dat Filipijnse tapijtschelpen voor de scholeksters in de Oosterschelde min of meer gelijkwaardig zijn als voedsel als de kokkel, zou de hoeveelheid voor scholeksters oogstbaar vlees van beide soorten in de voedselreservering mee kunnen worden genomen. Een interessant punt in deze is, dat de langjarige trend voor aantallen scholeksters in de hele Oosterschelde negatief is, maar dat juist in de twee deelgebieden waar de meeste tapijtschelpen liggen (centraal en oost) er recent sprake lijkt van stabilisatie of zelfs een toename in de aantallen scholeksters (van Donk et al., 2020). Gezien het feit dat de reservering van $150 \mathrm{~kg}$ kokkelvlees voor de scholeksters in de hele Oosterschelde echter niet heeft geleid tot een stabilisatie van de aantallen, moet deze grenswaarde wellicht hoger komen te liggen.

Voordat de rekenregels kunnen worden aangepast, moeten er nog wel enkele leemtes in kennis worden ingevuld.

Ontbrekende kennis: Vastgesteld moet worden of en zo ja in welke mate, scholeksters in de Oosterschelde tapijtschelpen eten. Daarnaast moet duidelijk worden of structureel voedselgebrek de oorzaak van de achteruitgang van de scholeksterstand is. Vervolgens moet worden vastgesteld of de scholeksters in de Oosterschelde voldoende voedsel beschikbaar hebben om de aantallen niet verder te laten dalen, dan wel te laten terugkeren op het gewenste niveau. Er moet hierbij een keuze worden gemaakt tussen de methode-Rappoldt et al. en de methode Goss-Custard/Stillman. 


\section{Conclusies en aanbevelingen}

A/B. Kan de Filipijnse tapijtschelp een volwaardige (en/of aanvullende) voedselbron zijn, welke evidentie is hiervoor en welke kennis ontbreekt nog?

- Tapijtschelpen en kokkels hebben een vergelijkbare morfometrie. Het belangrijkste verschil is dat tapijtschelpen groter kunnen worden.

- De ingraafdiepte van tapijtschelpen valt binnen de reikwijdte van scholeksters.

- Tapijtschelpen komen voor in allerlei dichtheden, ook in die van boven 50 per $\mathrm{m}^{2}$.

- $\quad$ Tapijtschelpen tolereren hogere temperaturen dan kokkels en kunnen in de toekomst bij klimaatverandering mogelijk de functie van kokkels overnemen.

- Het is nog niet aangetoond dat scholeksters in Nederland tapijtschelpen eten.

C. Uitgaande van een minimummaat van kokkels van $21 \mathrm{~mm}$ : is op basis van 'expert judgement' een minimummaat te adviseren van tapijtschelpen?

- De minimummaat van kokkels voor visserij is $21 \mathrm{~mm}$ schelplengte. Dit wordt bewerktstelligd door een spijlbreedte in de molens van maximaal $15 \mathrm{~mm}$ aan te houden. Bij deze afstand tussen de spijlen worden de eenjarige kokkels gespaard. Ook voor tapijtschelpen geldt dat de eenjarigen kleiner zijn dan $21 \mathrm{~mm}$ en deze bij een spijlbreedte van $15 \mathrm{~mm}$ worden gespaard. In de praktijk hoeft daarom de afstand tot te spijlen niet te worden aangepast en kan een gelijke minimummaat, van $21 \mathrm{~mm}$ schelplengte, voor beide soorten worden aangehouden.

D. Voor welke vogelsoorten kunnen Filipijnse tapijtschelpen in de Oosterschelde en het Grevelingenmeer een volwaardige en/of aanvullende voedselbron vormen?

- Schelpdieren worden door vier groepen van vogels gegeten: eenden, steltlopers, meeuwen en kraaien. Schelpdier-etende soorten die hier relevant zijn, dat wil zeggen tamelijk algemeen voorkomen en een Natura 2000-status hebben zijn: scholekster en brilduiker in het Grevelingenmeer en bergeend, bonte strandloper, drieteenstrandloper, kanoet, rosse grutto, scholekster, steenloper, wulp en zilverplevier in de Oosterschelde. Het is nog voor geen enkele vogelsoort duidelijk of deze in het Grevelingenmeer of in de Oosterschelde tapijtschelpen eten.

- Om vast te stellen of Filipijnse tapijtschelpen door vogels in deze gebieden worden gegeten is dieetonderzoek nodig middels gerichte observaties aan foeragerende vogels of door prooiresten in uitwerpselen te verzamelen.

E. Indien tapijtschelpen inderdaad als volwaardige alternatieve (en/of aanvullende) voedselbron aangemerkt kunnen worden, welke consequenties zou dit kunnen hebben voor de voedselreservering voor scholeksters in de Oosterschelde?

- Indien kan worden vastgesteld dat Filipijnse tapijtschelpen voor de scholeksters in de Oosterschelde min of meer gelijkwaardig zijn als voedsel als de kokkel, zou de hoeveelheid voor scholeksters oogstbaar vlees van beide soorten in de voedselreservering mee kunnen worden genomen.

- Daarnaast moet duidelijk worden of structureel voedselgebrek de oorzaak van de achteruitgang van de scholeksterstand is. Vervolgens moet worden vastgesteld of de scholeksters in de Oosterschelde voldoende voedsel beschikbaar hebben om de aantallen niet verder te laten dalen, dan wel te laten terugkeren op het gewenste niveau. Er moet hierbij een keuze worden gemaakt tussen de methode-Rappoldt et al. en de methode Goss-Custard/Stillman.

Concluderend kunnen we stellen, dat de Filipijnse tapijtschelp zich een plek heeft verworven binnen het ecosysteem van de Deltawateren en dat deze op termijn zelfs de functies van de kokkel zou kunnen gaan overnemen. Voedselreservering op basis van (alleen) de kokkel wordt steeds minder relevant. Bovendien heeft de huidige voedselreservering niet geleid tot herstel, of zelfs stabilisatie van 
de aantallen scholeksters in de Oosterschelde en het Grevelingenmeer, en is er kritiek mogelijk op de rekenregels die ten grondslag lagen aan de voedselreservering. Er zijn dus redenen om de systematiek van de voedselreservering te heroverwegen, al dient wel te worden aangetoond dat de tapijtschelpen (al) een belangrijke alternatieve voedselbron zijn voor de vogels in de Oosterschelde en het Grevelingenmeer. 


\section{Dankwoord}

Graag bedanken wij Susanne van Donk voor de gedeelde informatie over vogels in het Grevelingenmeer en Oosterschelde en Emiel Brummelhuis voor de metingen aan tapijtschelpen. 


\section{Kwaliteitsborging}

Wageningen Marine Research beschikt over een ISO 9001:2015 gecertificeerd kwaliteitsmanagementsysteem. Dit certificaat is geldig tot 15 december 2021. De organisatie is gecertificeerd sinds 27 februari 2001. De certificering is uitgevoerd door DNV GL. 


\section{Literatuur}

Arts F.A., Hoekstein M.S.J., Vergeer JW., van Kleunen A. \& Noordhuis R. 2019. Negatieve trends watervogels Natura 2000 Haringvliet en Grevelingen. Delta ProjectManagement Rapportnr. 2019-01. DPM, Vlissingen.

Baptist M.J. 2021. Natuurambities voor de Waddenzee. Landschap 2021/1: 6-13.

Beukhof E., van de Wolfshaar K., Tulp I. \& Beier U. 2021. De aard van het beestje zegt meer. De Levende Natuur 122: 51-55.

Breber P. 1985. On growing of the carpet shell clam (Tapes decussatus (L.)): Two Years' Experience In Venice Lagoon. Aquaculture 44: 51-56.

de Bruyne R.H. 2004. Veldgids Schelpen. Utrecht: KNNV, 234 pp., ISBN 90-5011-140-8

Bult, T.P. \& J.J. Kesteloo, 2002. Het kokkelbestand in de Nederlandse kustwateren in 2002. RIVO rapport nr. C038/02, $44 \mathrm{pp}$.

Cadée G.C. 2000. Herring Gulls feeding on a recent invader in the Wadden Sea, Ensis directus. Geological Society, London. Special Publications 177: 459-464.

Cadée G.C. 2001. Zilvermeeuwen profiteren van sterfte van Ensis directus. Zeepaard 61: 133-140.

Caldow R.W.G., Stillman R.A., le V. dit Durell S.E.A., West A.D., McGrorty S., Goss-Custard J.D., Wood P.J. \& Humphreys J. 2007. Benefits to shorebirds from invasion of a non-native shellfish. Proc. R. Soc. B 274: 1449-1455.

Camphuysen C.J. 2013. A historical ecology of two closely related gull species (Laridae): multiple adaptations to a man-made environment. :Proefschrift, Universiteit Groningen.

Camphuysen C.J., Berrevoets C.M., Cremers H.J.W.M., Dekinga A., Dekker R., Ens B.J., van der Have T.M., Kats R.K.H., Kuiken T., Leopold M.F., van der Meer J. \& Piersma T. 2002. Mass mortality of common eiders (Somateria mollissima) in the Dutch Wadden Sea, winter 1999/2000: starvation in a commercially exploited wetland of international importance. Biological Conservation 106: 303-317.

van Donk S., Ysebaert T. \& Tulp I. 2020. Trends van steltlopers en andere benthos etende vogels in de Oosterschelde: 1987 - 2017/2018. Wageningen Marine Research rapport C120/20, doi:10.18174/537451.

Drummond L Mulcahy M. \& Culloty S. 2006. The reproductive biology of the Manila clam, Ruditapes philippinarum, from the North-West of Ireland. Aquaculture 254: 326-340.

Durell S.E.A. Le V. Dit \& Kelly C.P. 1990. Diets of dunlin Calidris alpina and grey plover Pluvialis squatarola on the Wash as determined by dropping analysis. Bird Study 37: 44-47.

Van Eerden M.R. 1997. Patchwork: patch use, habitat exploitation and carrying capacity for water birds in Dutch freshwater wetlands. Proefschrift RDIJ. Lelystad.

Ens B.J., Kats R.K.H. \& Camphuysen C.J. 2006. Waarom zijn eiders niet massaal gestorven in de winter van 2005/2006? Limosa 79: 95-106.

Faasse M.A. \& Ligthart M. 2008. De exotische tapijtschelp Ruditapes philippinarum (Adams \& Reeve, 1850 ) vestigt zich in Nederland. Het Zeepaard 68: 175-179

Flassch J.P., \& Leborgne Y. 1992. Introduction in Europe, from 1972 to 1980, of the Japanese Manila clam (Tapes philippinarum) and effects on aquaculture production and natural settlement. ICES J. Mar. Sci. 194: 92-96.

Foekema E.M., Cuperus J. \& van der Weide B.E. 2014. Risk assessment of alien species found in and around the oyster basins of Yerseke IMARES Wageningen UR Rapport C014.14

Freudendahl A.S. \& Jensen K.T. 2006. Population dynamics of the American razor clam (Ensis americanus) at Horns Rev. Dept of Marine Ecology, Univ. Aarhus, Denemarken, 23p.

van Gils J.A., van der Geest M., Leyrer J., Oudman T., Lok T., Onrust J., de Fouw J., van der Heide T., van den Hout P.J., Spaans B., Dekinga A., Brugge M. \& Piersma T. 2013. Toxin constraint explains diet choice, survival and population dynamics in a molluscivore shorebird. Proc. R. Soc. B 280: 20130861.

Goss-Custard J. D. \& Stillman R.A. 2020. How manual cockle-raking may affect availability of cockles Cerastoderma edule for oystercatchers Haematopus ostralegus in the Dutch Wadden Sea. BU Global Environmental Solutions report BUG2842 to Province of Fryslân. 
Hulscher J.B. 1982. The oystercatcher Haematopus ostralegus as a predator of the bivalve Macoma balthica in the Dutch Wadden Sea. Ardea 70: 89-152.

Houziaux J.-S., Craeymeersch J., Merckx B., Kerckhof F., Van Lancker V., Courtens W., Stienen E., Rabaut M., Perdon J., Goudswaard P.C., Van Hoey G., Vigin L., Hostens K., Vincx M. \& Degraer S. 2011. 'EnSIS' - Ecosystem Sensitivity to Invasive Species. Final Report, Belgian Science Policy, Brussels: Research Programme Science for a Sustainable Development.

Humphreys J., Harris M.R.C., Herbert R.J.H., Farrell P., Jensen A. \& Cragg S.M. 2015. Introduction, dispersal and naturalization of the Manila clam Ruditapes philippinarum in British estuaries, 1980-2010. J. Mar. Biol. Assoc. UK 95: 1163-1172

Iglesias J.I.P. \& E. Navarro (1991) Energetics of growth and reproduction in cockles (Cevastoderma edule): seasonal and age-dependent variations. Marine Biology 111, 359-368

Jansen H., Kamermans P., Glorius S. \& van Asch M. 2019. Draagkracht van de Oosterschelde en westelijke Waddenzee voor schelpdieren - Evaluatie van veranderingen in de voedselcondities en schelpdierbestanden in relatie tot de mosselkweek in de periode 1990-2016. Wageningen Marine Research rapport C096/19.

Jensen A.C., Humphreys J., Caldow R.W.G., Grisley C. \& Dyrynda P.E.J. 2004 Naturalization of the Manila clam (Tapes philippinarum), an alien species, and establishment of a clam fishery within Poole Harbour, Dorset. J. Mar. Biol. Assoc. UK 84: 1069-1073.

Jung A.S., van der Veer H.W., Philippart C.J.M., Waser A.M., Ens B.J., de Jonge V.N. \& Schückel U. 2020. Impacts of macrozoobenthic invasions on a temperate coastal food web. Mar. Ecol. Prog. Ser. 653: 19-39.

Kurihara T., Hashimoto K., Nakano S., Matsuyama Y., Ito A., Kanematsu M., Okamura K. 2018. Horizontal and vertical variations in survival rates of juvenile bivalves, Anadara kagoshimensis (Tokunaga, 1906), Ruditapes philippinarum (Adams \& Reeve, 1850) and Atrina sp., experimentally caged in the inner area of the Sea of Ariake, Japan. Int. Aquat. Res. 10: 349359.

de Leeuw J. 1997. Demanding divers - Ecological energetics of food exploitation by diving ducks. Proefschrift Universiteit Groningen.

Leopold M.F. \& Wolf P. 2003. Zee-eenden eten ook Ensis. Nieuwsbrief Nederlandse Zeevogelgroep 4(3): 5 .

Leopold M.F., Smit C.J., Goedhart P.W., van Roomen M.W.J., van Winden A.J. \& van Turnhout C. 2004. Langjarige trends in aantallen wadvogels, in relatie tot de kokkelvisserij en het gevoerde beleid in deze. Eindverslag EVA II (Evaluatie Schelpdiervisserij tweede fase), Deelproject C2. Alterra-rapport 954.

Leopold M.F., Spannenburg P.C., Verdaat H.J.P. \& Kats R.K.H. 2007. Identification and size estimation of Spisula subtruncata and Ensis americanus from shell fragments in stomachs and faeces of Common Eiders Somateria mollissima and Common Scoters Melanitta nigra. Ch 4 in: R.K.H. Kats. Common Eiders Somateria mollissima in the Netherlands. The rise and fall of breeding and wintering populations in relation to the stocks of shellfish. Proefschrift Universiteit Groningen, pp 63-85.

Leopold M., van Asch M., Dijkman E., Goudswaard K., Lagerveld S., Verdaat H., Camphuysen K. \& ten Horn J. 2014. Zwarte zee-eenden bij Texel, een reactie op overvloedig voorkomen van Ensis? IMARES Rapport C084/14.

Lopez-Joven C., de Blas I. \& Roque A. 2018. Temperature effects on the growth and survival of tdh positive Vibrio parahaemolyticus in tissues of postharvest Manila clam (Ruditapes philippinarum). Food Microbiology 75: 61-64

Ministerie van Landbouw, Natuurbeheer en Visserij 1998. Structuurnota Zee- en kustvisserij. Evaluatie van de maatregelen in de kustvisserij gedurende de eerste fase (1993-1997). Rapportage van implementatie beleidspunten en beheersmaatregelen. Ecologisch en sociaal-economisch onderzoek. Uitvoering Beheersplan Kustvisserij. Handhaving en sanctionering. Den Haag, Groningen, maart 1998.

Mortensen S.H., Strand $\varnothing . \&$ Høisœter T. 2000. Releases and recaptures of Manila clams (Ruditapes philippinarum) introduced to Norway. : 87-91.

Nerlovic V., Korlevic M.\& Mravinac B. 2016. Morphological and molecular differences between the invasive bivalve Ruditapes philippinarum (Adams \& Reeve, 1850) and the native species Ruditapes decussatus (Linnaeus, 1758) from the northeastern Adriatic sea. J. Shellfish Res. 35: 31-39. 
Nie H., Jiang L., Huo Z., Liu L., Yang F. \& Yan X. 2016. Transcriptomic responses to low temperature stress in the Manila clam, Ruditapes philippinarum. Fish \& Shellfish Immunology 55: 358-366.

Noordhuis R., Groot S., Pires M.D. \& Maarse M. 2014. Wetenschappelijk eindadvies ANTIJsselmeergebied. Vijf jaar studie naar kansen voor het ecosysteem van het IJsselmeer, Markermeer en IJmeer met het oog op de Natura-2000 doelen. Rapport Rijkswaterstaat/Deltares, Lelystad. Kenmerk 1207767-000-ZWS-0005.

Philippart K. 2018. Hitte is de nieuwe kou. Inaugurele rede uitgesproken bij de aanvaarding van het bijzonder hoogleraarschap Productivity of Coastal Marine Systems aan de faculteit Geowetenschappen van de Universiteit Utrecht, op 14 november 2018.

Rappoldt C., Ens B.J., Berrevoets C.M., Geurts van Kessel a.J.M., Bult T.P. \& Dijkman E.M. 2003. Scholeksters en hun voedsel in de Oosterschelde; Rapport voor deelproject D2 thema 1 van EVA II, de tweede fase van het evaluatieonderzoek naar de effecten van schelpdiervisserij op natuurwaarden in de Waddenzee en Oosterschelde 1999-2003. Alterra Rapport 883, Wageningen.

Savage N.B. 1976. Burrowing activity in Mercenaria mercenaria (L.) and Spisula solidissima (Dillwyn) as a function of temperature and dissolved oxygen. Marine Behaviour and Physiology 3: 221234.

Schwemmer P., Volmer H., Enners L., Reimers H.-C., Binder K., Horn S., Adler S., Fox A.D. \& Garthe S. 2019. Modelling distribution of common scoter (Melanitta nigra) by its predominant prey, the American razor clam (Ensis leei) and hydrodynamic parameters. Estuarine, Coastal and Shelf Science 225 (2019) 106260.

Shin Y.-K., Kim Y., Chung E.-Y., \& Hur S.-B. 2000. Temperature and salinity tolerance of the Manila clam, Ruditapes philippinarum. Korean Journal of Fisheries and Aquatic Sciences 33: 213218.

Skov H., Durinck J., Erichsen A., Kloster R.M., Møhlenberg F. \& Leonard S.B. 2008. Horns Rev II offshore wind farm food basis for common scoter. Baseline studies 2007-2008. Report commissioned by DONG energy, Orbicon/DHI/Marine Observers, 46p.

https://tethys.pnnl.gov/sites/default/files/publications/Food_Basis_for_Common_Scooter_Hor ns_Rev_II.pdf

Smaal A.C 2020. Tapijtschelpen in de Oosterschelde. Karakteristieken en mogelijkheden voor duurzame exploitatie. Rapport Shellfish Consultancy, Zierikzee.

van Stralen M.R., 1990. Het kokkelbestand in de Oosterschelde en de Waddenzee in 1990. RIVO rapport AQ 90-0.

Swennen C. \& Duiven P. 1989. Eidereend Somateria mollissima gestikt in Amerikaanse zwaardscheden. Limosa 62: 153-154.

Swennen C., Leopold M.F. \& Stock M. 1985. Notes on growth and behaviour of the American razor clam Ensis directus in the Wadden Sea and the predation on it by birds. Helgoländer Meeresunters. 39: 255-261.

Swennen C., de Bruijn L.L.M., Duiven P., Leopold M.F. \& Marteijn E.C.L. 1983. Differences in bill form of the oystercatcher Haematopus ostralegus; a dynamic adaptation to specific foraging techniques. Neth. J. Sea Res. 17: 57-83.

Titselaar F.F.L.M. 2008. Tapes philippinarum (Adams and Reeve, 1850) in de Oosterschelde. Spirula, nr. 365: 1-2.

Troost K. 2021. Filipijnse tapijtschelp massaal in Zeeland. Visserijnieuws, 41(16): 20-21. Special schaal- en schelpdieren \& aquacultuur.

Troost K., Brummelhuis E.B.M., van Asch M \& van Zwol J 2017. Schelpdierbestanden in het Veerse meer en Grevelingenmeer in 2017. CVO rapport 17.015.

Troost K. \& van Asch M. 2018. Herziene schatting van het kokkelbestand in de Waddenzee en Oosterschelde in het najaar van 2018. CVO Rapport 18.014

Troost K, van Asch M., Brummelhuis E., van den Ende D., van Es Y., Perdon K.J., van der Pool J., van Zweeden C. \& van Zwol J. 2021 Schelpdierbestanden in de Nederlandse kustzone, Waddenzee en zoute deltawateren in 2020. CVO rapport 21.001.

Tulp I., Craeymeersch J., Leopold M., van Damme C., Fey F. \& Verdaat H. 2010. The role of the invasive bivalve Ensis directus as food source for fish and birds in the Dutch coastal zone. Estuarine, Coastal and Shelf Science 90: 116-128. 
van de Pol M., Ens B.J., Oosterbeek K., Brouwer L., Verhulst S., Tinbergen J.M., Rutten A.L. \& de Jong M. 2009. Oystercatcher's bill shapes as a proxy for diet specialization: more differentiation than meets the eye. Ardea 97: 335-347.

Verdelhos T., Marques J. \& Anastácio P., 2015. Behavioral and mortality responses of the bivalves Scrobicularia plana and Cerastoderma edule to temperature, as indicator of climate change's potential impacts. Ecological Indicators 58: 95-103.

Wijsman J.W.M. \& Smaal A.C. 2006. Risk analysis of mussels transfer. Wageningen IMARES Rapport C044/06.

Wilson J. \& Elkaim B., 1997. Seasonal and geographical differences in oxygen consumption with temperature of Cerastoderma glaucum (Poiret) and a comparison with C. edule (L.). Estuarine, Coastal and Shelf Science 45: 571-577.

Zwarts L. \& Wanink J.H. 1993. How the food supply harvestable by waders in the Wadden Sea depends on the variation in energy density, body weight, biomass, burying depth and behaviour of tidal-flat invertebrates.. Netherlands Journal of Sea Research 31 (4): 441-476. 


\section{Verantwoording}

Rapport C053/21

Projectnummer: 4318100373

Dit rapport is met grote zorgvuldigheid tot stand gekomen. De wetenschappelijke kwaliteit is intern getoetst door een collega-onderzoeker en het verantwoordelijk lid van het managementteam van Wageningen Marine Research

Akkoord:

Dr. J.A. Craeymeersch

onderzoeker

Handtekening:

Datum:

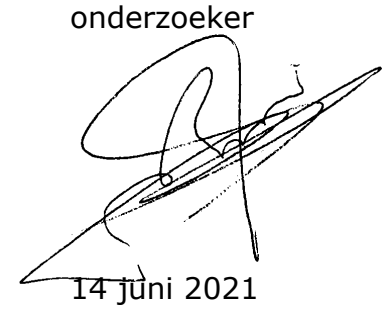

Akkoord:

Drs. J. Asjes

Manager Integratie

Handtekening:

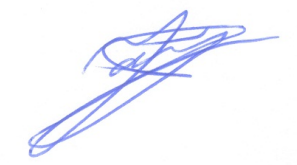

Datum:

14 juni 2021 
Wageningen Marine Research

T: $+31(0) 317487000$

E: marine-research@wur.nl

www.wur.nl/marine-research

Bezoekers adres:

- Ankerpark 271781 AG Den Helder

- Korringaweg 7, 4401 NT Yerseke

- Haringkade 1, 1976 CP IJmuiden
Wageningen Marine Research levert met kennis, onafhankelijk wetenschappelijk onderzoek en advies een wezenlijke bijdrage aan een duurzamer, zorgvuldiger beheer, gebruik en bescherming van de natuurlijke rijkdommen in zee-, kust- en zoetwatergebieden.
Wageningen Marine Research is onderdeel van Wageningen University \& Research. Wageningen University \& Research is het samenwerkingsverband tussen Wageningen University en Stichting Wageningen Research en heeft als missie: 'To explore the potential of nature to improve the quality of life' 